\title{
14. NEOGENE AND QUATERNARY CALCAREOUS NANNOFOSSIL BIOSTRATIGRAPHY OF THE WALVIS RIDGE ${ }^{1}$
}

\author{
Ming-Jung Jiang, Robertson Research (U.S.) Inc., Houston, Texas \\ and \\ Stefan Gartner, Department of Oceanography, Texas A\&M University, \\ College Station, Texas
}

\begin{abstract}
During DSDP Leg 74 in the South Atlantic, 11 holes were drilled at 5 sites (525-529) on the eastern end of Walvis Ridge. The sediments recovered range in age from late Campanian or early Maestrichtian to Holocene. This chapter deals only with the Neogene to Holocene interval. The calcareous nannofossils over this interval have been corroded as well as overgrown, but a precise biostratigraphy is possible at all sites because most of the key index species are present.
\end{abstract}

\section{INTRODUCTION}

During DSDP Leg 74, 11 holes were drilled at 5 sites (525-529) on Walvis Ridge in the South Atlantic near South Africa (Fig. 1). Sediments ranging in age from late Campanian or early Maestrichtian to Holocene were recovered. This chapter deals with the calcareous nannofossils found in the Neogene to Holocene sediment from these five sites. The calcareous nannofossils from the Paleogene and the Upper Cretaceous are documented by Hélene Manivit in this same volume.

Calcareous nannofossils from the Neogene through Holocene recovered during DSDP Leg 74 are abundant at all sites, except for the middle Miocene red clay interval cored at Site 527-the deepest site. Their state of preservation, however, is ranked as "moderate" in general. Dissolution and recrystallization have progressed to such an extent that only solution-resistant or robust forms can be recognized for most of the middle and lower Miocene sections. Fortunately, most of the zonal markers are present and can be identified with certainty. The main purpose of this chapter is, therefore, to document the biostratigraphic distribution of the calcareous nannofossils rather than to do a complete taxonomic study.

Smear slides of the original unprocessed samples were examined with a light microscope for this study. In order to obtain a precise position of the zonal boundaries, one sample was taken for each section $(150 \mathrm{~cm})$ of a core and investigated for its calcareous nannofossil content. For some critical intervals, more closely spaced samples were analyzed. Therefore the stratigraphic first and last appearance of the selected species was determined with an accuracy of $150 \mathrm{~cm}$ or less for this report. Checklists of a selected set of species were prepared for each site.

\footnotetext{
${ }^{1}$ Moore, T. C., Jr., Rabinowitz, P. D., et al., Init. Repts. DSDP, 74: Washington (U.S. Govt. Printing Office).
}

\section{CALCAREOUS NANNOFOSSIL ZONATION}

Martini's standard Tertiary and Quaternary zonation (1971), which is widely used elsewhere, was the starting basis for the zonation described here. Because of the scarcity or apparent lack of some of Martini's index fossils, possibly owing to environmental exclusion of the parent organism or to poor preservation, other species were selected to determine zones. Deviations from Martini's zonation, necessary for the studied area, are discussed in the following. The age and zone assignments of the Neogene through Holocene cores based on this modified zonation are then given in Table 1.

\section{Triquetrorhabdulus carinatus Zone (NN1)}

Definition. Interval from the last occurrence of Helicosphaera recta to the first occurrence of Discoaster druggii above it.

Remarks. Because of environmental exclusion, Helicosphaera recta together with $H$. perch-nielseniae is present only at Site 526, the shallowest site. The last occurrence of Sphenolithus ciperoensis is tentatively used to define the base of Zone NN1, i.e., the Oligocene/ Miocene boundary, in this study. Other important and solution-resistant species, which become extinct slightly above the last occurrence of Sphenolithus ciperoensis, are Dictyococcites bisectus (Dictyococcites abisectus included), aff. D. dictyodus, S. capricornutus, S. delphix, and Zygrhablithus bijugatus. S. capricornutus and S. delphix have very short ranges. Both forms first occur above the last occurrence of $S$. ciperoensis and become extinct at about the same level as Dictyococcites bisectus, aff. D. dictyodus, and Z. bijugatus.

Because of the strong overgrowth of discoasters within this interval, typical specimens of Discoaster druggii cannot be identified with certainty. The first occurrence of an unusual form of discoaster is at the top of Zone NN1. This species is consistently much larger and more robust than the common $D$. deflandrei specimens in this interval. It has straight and slightly tapered rays and is documented as Discoaster sp. aff. $D$. druggii in this study.

\section{Discoaster druggii Zone (NN2)}

Definition. Interval from the first occurrence of Discoaster druggii to the last occurrence of Triquetrorhabdulus carinatus.

Remarks. The first occurrence of Discoaster sp. aff. D. druggii is used to mark the base of Zone NN2, whereas the first occurrence of Sphenolithus belemnos marks the top of this zone in this study. This zone is therefore equivalent to Zone CN1C of Okada and Bukry (1980). 


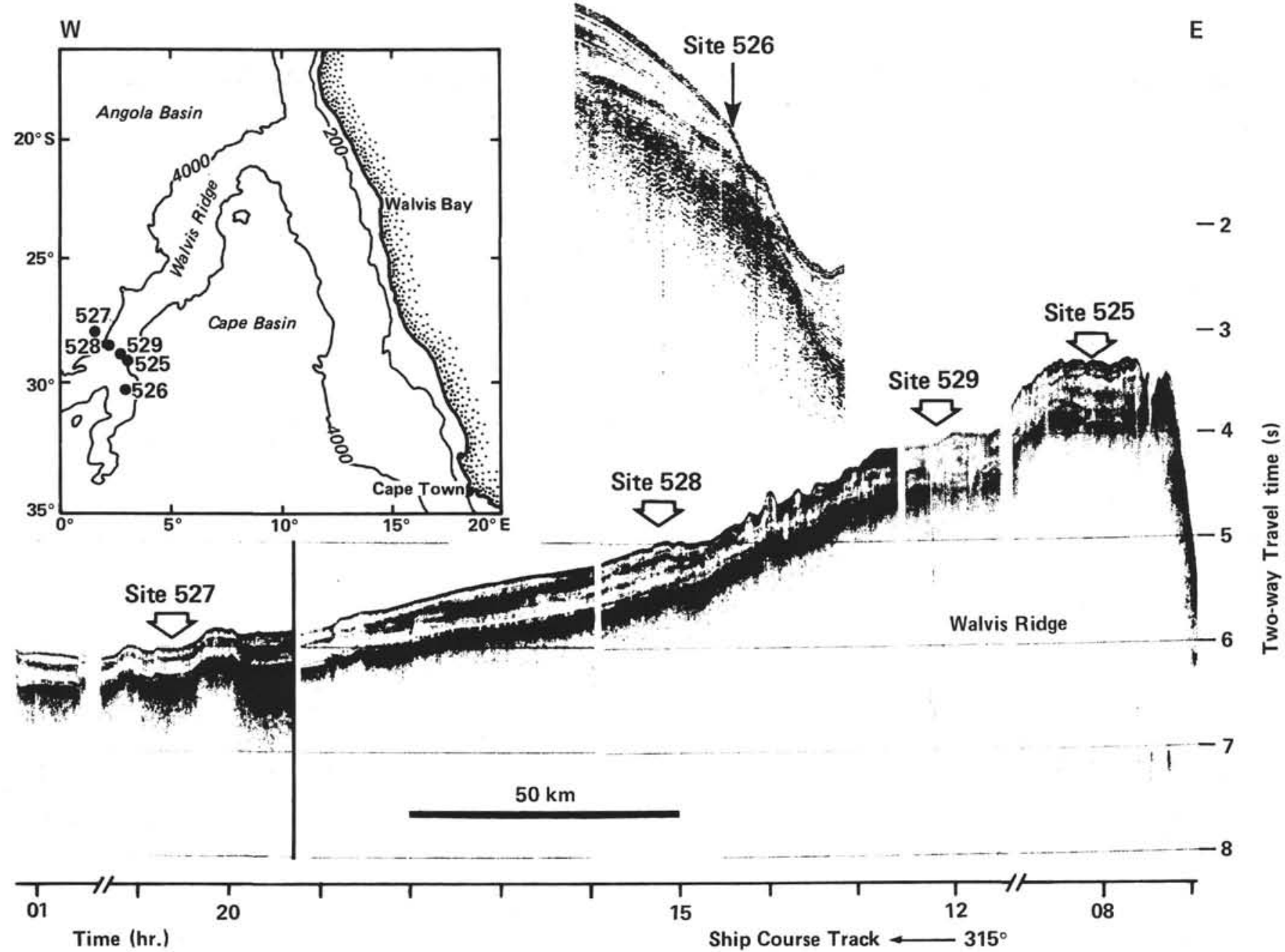

Figure 1. Site locations on the Walvis Ridge in the South Atlantic Ocean for DSDP Leg 74.

The last occurrence of $T$. carinatus is uncertain, because in some cases it is difficult to distinguish $T$. carinatus from an elongate calcite lath in an assemblage with moderate or poor preservation and recrystallization. Reticulofenestra pseudoumbilica sample and Calcidiscus leptoporus have their first occurrence in this zone.

\section{Sphenolithus belemnos Zone (NN3)}

Definition. Interval from the last occurrence of Triquetrorhabdulus carinatus to the last occurrence of Sphenolithus belemnos.

Remarks. The total range of $S$, belemnos marks Zone NN3 in this study. Sphenolithus sp. aff. $S$. belemnos documented in the tables could be small specimens of $S$. dissimilis.

\section{Helicosphaera ampliaperta Zone (NN4)}

Definition. Interval from the last occurrence of Sphenolithus belemnos to the last occurrence of Helicosphaera ampliaperta.

Remarks. S. heteromorphus first occurs immediately above the extinction of $S$. belemnos. Neither gap nor overlap of the ranges of the two species is observed at the studied sites. The first occurrence of $S$. heteromorphus may be a good marker for the boundary of Zones NN3 and NN4 (Bukry, 1972, 1973).

The index fossil, $H$. ampliaperta, is absent, probably because of ecological exclusion. The first common occurrence of Discoaster variabilis s. ampl. is tentatively used to mark the top of Zone NN4, i.e., the top of the lower Miocene. (The lower Miocene/middle Miocene boundary is for the sake of convenience somewhat arbitrarily placed at the top of the $H$. ampliaperta Zone, recognizing, however, that the boundary has been identified variously as older, equal to, and younger than this datum.)

\section{Sphenolithus heteromorphus Zone (NN5)}

Definition. Interval from the last occurrence of Helicosphaera ampliaperta to the last occurrence of Sphenolithus heteromorphus.

Remarks. At the boundary of Zones NN4/NN5, i.e., the lower/ middle Miocene boundary, assemblages of discoaster change significantly. Discoaster deflandrei, which is a dominant species in the lower Miocene, is replaced abruptly by (overgrown) $D$. variabilis, although the former persists upward. The first common occurrence of $D$. variabilis s. ampl. is therefore used to make the base of Zone NN5 because this datum is easy to recognize (see Bukry, 1973).

The top of this zone is also easy to recognize in the studied sites.

\section{Discoaster exilis Zone (NN6)}

Definition. Interval from the last occurrence of Sphenolithus heteromorphus to the first occurrence of Discoaster kugleri.

Remarks. Because of strong overgrowth of discoasters, typical $D$. kugleri cannot be identified with certainty. The top of Zone NN6 is therefore placed at the last occurrence of Cyclicargolithus floridanus, a species which is common within and below this zone (see, e.g., Bukry, 1975).

Coronocyclus nitescens seems to become extinct within this zone, whereas Triquetrorhabdulus rugosus has its first occurrence in this zone. 
Table 1. Zonal and geologic age assignments of Leg 74 cores, based on calcareous nannofossils in samples from holes at Sites 525-529.

\begin{tabular}{|c|c|c|c|c|c|c|c|c|c|c|c|c|c|c|}
\hline \multicolumn{2}{|c|}{ Age } & \multicolumn{2}{|r|}{$\begin{array}{l}\text { Calcareous Nannofossil } \\
\text { Zonation (Martini, 1971) }\end{array}$} & 525 & $525 \mathrm{~A}$ & $525 \mathrm{~B}$ & 526 & $526 \mathrm{~A}$ & $526 \mathrm{~B}$ & $526 \mathrm{C}$ & 527 & 528 & $528 \mathrm{~A}$ & 529 \\
\hline \multirow{3}{*}{ Pleistocene } & \multirow{2}{*}{ late } & NN21 & Emiliania huxleyi & & & $\begin{array}{l}1-1,30-32 \\
1-1,80-82 \\
\end{array}$ & & & & & & & & $\begin{array}{l}1-1, \text { top } \\
1-1,40-41\end{array}$ \\
\hline & & $\mathrm{NN} 20$ & Gephyrocapsa oceanica & & & $1-2,30-32$ & $\begin{array}{l}1-1,101-102 \\
2-1,106-107\end{array}$ & & & & & $1-1,20-21$ & $1-1,28-29$ & $1-1,150$ \\
\hline & early & NN19 & Pseudoemiliania lacunosa & $1, \mathrm{CC}$ & $1, \mathrm{CC}$ & $\begin{array}{l}1-2,80-82 \\
3-1,76-78\end{array}$ & $2, \mathrm{CC}$ & & $\begin{array}{l}1-1,30-32 \\
3-1,35-36\end{array}$ & & $\begin{array}{l}1-1,29-31 \\
2-1,50-51\end{array}$ & $\begin{array}{l}1-2,20-21 \\
1, \mathrm{CC}\end{array}$ & $\begin{array}{l}1-1,120-122 \\
5-3,19-20\end{array}$ & $\begin{array}{l}1-2,40-41 \\
2-6,40-41\end{array}$ \\
\hline \multirow{7}{*}{ Pliocene } & \multirow{3}{*}{ late } & NN18 & Discoaster brouweri & & & $\begin{array}{l}3-2,53-54 \\
4-1,75-77 \\
\end{array}$ & & & $\begin{array}{l}3-2,35-36 \\
3, \mathrm{CC}\end{array}$ & & $2, \mathrm{CC}$ & & $\begin{array}{l}5-4,19-20 \\
6-3,19-20\end{array}$ & $2, \mathrm{CC}$ \\
\hline & & NN17 & Discoaster pentaradiatus & & & $4-2,65-66$ & & & & & $3-1,35-37$ & & & \\
\hline & & NN16 & Discoaster surculus & & & $\begin{array}{l}4-3,65-66 \\
5-1,81-83\end{array}$ & & & & & $\begin{array}{l}3-1,50-51 \\
3-4,35-37\end{array}$ & & $\begin{array}{l}6-3,111 \\
7-2,100\end{array}$ & $3-1,30-31$ \\
\hline & \multirow{4}{*}{ early } & NN15 & $\begin{array}{l}\text { Reticulofenestra } \\
\quad \text { pseudoumbilica } \\
\end{array}$ & & & $\begin{array}{l}5-2,81-83 \\
8-2,86-87 \\
\end{array}$ & & $1-1,75-76$ & $\begin{array}{l}4-2,20-21 \\
5, \mathrm{CC}\end{array}$ & $\begin{array}{l}1-1,100 \\
1, \mathrm{CC}\end{array}$ & $\begin{array}{l}3-4,50-51 \\
5, \mathrm{CC}\end{array}$ & & $\begin{array}{l}7-3,40-41 \\
11-3, \text { top }\end{array}$ & $\begin{array}{l}3-2,30-31 \\
4-6,40-41 \\
\end{array}$ \\
\hline & & NN14 & Discoaster asymmetricus & & & $8-3,3-4$ & & $1-2,75-76$ & & & $6-1,40-42$ & & $\begin{array}{l}11, \mathrm{CC} \\
13-2,63-64\end{array}$ & $4, \mathrm{CC}$ \\
\hline & & NN13 & Ceratolithus rugosus & & $3-1,29-30$ & $12-1,10-11$ & & $\begin{array}{l}1-3,75-76 \\
2-2,80-81\end{array}$ & & & $6-2,40-42$ & & $13-3,63-64$ & \\
\hline & & NN12 & Amaurolithus tricorniculatus & & $4-1,148-149$ & $\begin{array}{l}12-1,54-55 \\
14-2,40-41 \\
\end{array}$ & & $\begin{array}{l}2-3,80-81 \\
5-1,85-86 \\
\end{array}$ & & $\begin{array}{l}2-1,42-43 \\
2-7,40-42 \\
\end{array}$ & $7-2,60-62$ & & $\begin{array}{l}\text { 13-4, base } \\
14-2,51-52\end{array}$ & \\
\hline \multirow{11}{*}{ Miocene } & \multirow{2}{*}{ late } & NN11 & Discoaster quinqueramus & & $\begin{array}{l}5-1,60-61 \\
6, C C\end{array}$ & $\begin{array}{l}14-2,100-101 \\
24, \mathrm{CC}\end{array}$ & & $\begin{array}{l}5-2,85-86 \\
9, \mathrm{CC}\end{array}$ & & $\begin{array}{l}2, \mathrm{CC} \\
3, \mathrm{CC} \\
\end{array}$ & $\begin{array}{l}7, \mathrm{CC} \\
13-1,10 \\
\end{array}$ & & $\begin{array}{l}14, \mathrm{CC} \\
24, \mathrm{CC} \\
\end{array}$ & \\
\hline & & NN10 & Discoaster calcaris & & & $\begin{array}{l}25-1,36-37 \\
28, \mathrm{CC}\end{array}$ & & $\begin{array}{l}10-1,103-104 \\
12-3,25-26\end{array}$ & & & $\begin{array}{l}13-1,15 \\
13-1,50 \\
\end{array}$ & & $\begin{array}{l}25-1,59-60 \\
25, \mathrm{CC}\end{array}$ & \\
\hline & \multirow{5}{*}{ middle } & NN9 & Discoaster hamatus & & & $\begin{array}{l}29-1,76-77 \\
32-2,113-114\end{array}$ & & $\begin{array}{l}12, \mathrm{CC} \\
14, \mathrm{CC}\end{array}$ & & & $\begin{array}{l}13-1,63 \\
13-5,44\end{array}$ & & $\begin{array}{l}26-1,50 \\
27-2,38-39\end{array}$ & \\
\hline & & NN8 & Catinaster coalitus & & & $\begin{array}{l}32-3,41-42 \\
33, \mathrm{CC}\end{array}$ & & $\begin{array}{l}15-1,26-27 \\
15, \mathrm{CC}\end{array}$ & & & $\begin{array}{l}13-5,66 \\
13-6,129 \\
\end{array}$ & & $\begin{array}{l}27-2,150 \\
27, \mathrm{CC}\end{array}$ & $\begin{array}{l}5-1, \text { top } \\
5, \mathrm{CC}\end{array}$ \\
\hline & & NN7 & Discoaster kugleri & & & $\begin{array}{l}34-1,65-66 \\
36, \mathrm{CC}\end{array}$ & & $\begin{array}{l}16-1,42-43 \\
18-3,50-51 \\
\end{array}$ & & & & & $\begin{array}{l}28-1,58 \\
28, \mathrm{CC}\end{array}$ & \\
\hline & & NN6 & Discoaster exilis & . & $\begin{array}{l}7-1,84-85 \\
8-2,40-41 \\
\end{array}$ & $\begin{array}{l}37-1,40-41 \\
41, \mathrm{CC}\end{array}$ & & $\begin{array}{l}18, C C \\
20-2,78-79\end{array}$ & & & & & & $\begin{array}{l}6-1,38 \\
6-6,100 \\
\end{array}$ \\
\hline & & NN5 & Sphenolithus heteromorphus & & $\begin{array}{l}8-3,40-41 \\
9, \mathrm{CC}\end{array}$ & $\begin{array}{l}42-1,35-36 \\
46-1,60-61 \\
\end{array}$ & & $\begin{array}{l}20-3,78-79 \\
20, \mathrm{CC}\end{array}$ & & & & $\begin{array}{l}2-1,0-1 \\
3-1,23-24\end{array}$ & & $\begin{array}{l}6-6,150 \\
6, \mathrm{CC} \\
\end{array}$ \\
\hline & \multirow{4}{*}{ early } & $\mathrm{NN} 4$ & Helicosphaera ampliaperta & & $\begin{array}{l}10-6,40-41 \\
11-1,40-41 \\
\end{array}$ & $\begin{array}{l}46-2,60-61 \\
48-1,60-61 \\
\end{array}$ & & $21-1,70-71$ & & & & $3-1,117$ & & $\begin{array}{l}7-1,65-66 \\
8-3,66\end{array}$ \\
\hline & & NN3 & Sphenolithus belemnos & & $\begin{array}{l}11-2,40-41 \\
11-4,40-41 \\
\end{array}$ & $\begin{array}{l}48-1,100-102 \\
49-3,20-21\end{array}$ & & $\begin{array}{l}21-2,70-71 \\
21, \mathrm{CC}\end{array}$ & & & & $\begin{array}{l}3, \mathrm{CC} \\
4-3,110\end{array}$ & & $\begin{array}{l}8-4,30-31 \\
8-6,30-31 \\
\end{array}$ \\
\hline & & NN2 & Discoaster druggii & & $\begin{array}{l}11-5,40-41 \\
13-4,40-41 \\
\end{array}$ & $\begin{array}{l}49-4,20-21 \\
49, \mathrm{CC}\end{array}$ & & $22-1,85-86$ & & & & $\begin{array}{l}4-3,131 \\
4-4,67\end{array}$ & & $\begin{array}{l}8-7,30-31 \\
9-5,30-31 \\
\end{array}$ \\
\hline & & NN1 & Triquetrorhabdulus carinatus & & $\begin{array}{l}13-5,40-41 \\
17-2,40-41\end{array}$ & & & $\begin{array}{l}22-2,85-86 \\
30, \mathrm{CC}\end{array}$ & & & & $\begin{array}{l}4-5,25-26 \\
6, \mathrm{CC}\end{array}$ & & $\begin{array}{l}9-6,30-31 \\
13-4,30-31 \\
\end{array}$ \\
\hline \multicolumn{2}{|c|}{ Oligocene } & NP25 & Sphenolithus ciperoensis & & $17, \mathrm{CC}$ & & & $\begin{array}{l}31-1,57-58 \\
31, \mathrm{CC}\end{array}$ & & & & $\begin{array}{l}7-1,10-12 \\
7, \mathrm{CC}\end{array}$ & $\begin{array}{l}29-1,20 \\
30-1,147\end{array}$ & $\begin{array}{l}13-5,30-31 \\
13, \mathrm{CC}\end{array}$ \\
\hline
\end{tabular}




\section{Discoaster kugleri Zone (NN7)}

Definition. Interval from the first occurrence of Discoaster kugleri to the first occurrence of Catinaster coalitus.

Remarks. According to the definition, the top of this zone is at the first occurrence of $C$. coalitus. However, in an assemblage with moderate recrystallization, $C$. coalitus is difficult to identify, whereas $C$. calyculus is still recognizable. In this case, the first occurrence of $C$. calyculus is used to mark the top of Zone NN7.

Discoaster deflandrei was not recorded above this zone.

\section{Catinaster coalitus Zone (NN8)}

Definition. Interval from the first occurrence of Catinaster coalitus or C. calyculus to the first occurrence of Discoaster hamatus.

\section{Discoaster hamatus Zone (NN9)}

Definition. Interval from the first occurrence to the last occurrence of Discoaster hamatus.

Remarks. D. hamatus in these southeast Atlantic sites is rare and much smaller than in other regions. In some cases $D$. bellus with slightly rotated tips (all in the same direction) resembles small $D$. hamatus. These two species are probably closely related to each other. Both forms have the same first occurrence at the base of Zone NN9; however, $D$. bellus extends upward to the lower part of Zone NN10.

$D$. pentaradiatus and $D$. neohamatus have their first occurrence in the upper part of this zone. Rare to common Minylitha convallis also occur in the upper part of this zone.

\section{Discoaster calcaris Zone (NN10)}

Definition. Interval from the last occurrence of Discoaster hamatus to the first occurrence of $D$. quinqueramus.

Remarks. The composition of discoasters of the assemblage has a second major change at the base of this zone, that is, at the base of the upper Miocene. The common (overgrown) D. variabilis s. ampl. is reduced in numbers, whereas delicate species such as $D$. brouweri (including large $D$. neorectus), $D$. calcaris, and $D$. neohamatus commonly occur in this zone in our cores.

Zone NN10 is also characterized by the abundant occurrence of Minylitha convallis. $M$. convallis looks like a calcite particle. However, when it occurs abundantly, it is easy to recognize the presence of this species in the assemblages.

\section{Discoaster quinqueramus Zone (NN11)}

Definition. Interval from the first to the last occurrence of Discoaster quinqueramus.

Remarks. Most of the Discoaster quinqueramus (group) specimens identified in this study are of the $D$. berggrenii type with short rays. This latter species is very rare at shallow sites. It is absent at deep sites, which makes it difficult to differentiate this zone from the superjacent and subjacent zones.

The lower part of Zone NN11 is characterized by the presences of D. neohamatus and Minylitha convallis, whereas the upper part is characterized by the presences of Amaurolithus spp. The ranges of $D$. neohamatus and $A$. primus show little overlap. However, these two species do co-occur in a few samples.

At deeper sites where $D$. quinqueramus is missing, the last occurrence of $A$. amplificus is tentatively introduced to mark the top of Zone NN11. This is based on the fact that $A$. amplificus is restricted to the $D$. quinqueramus Zone at the shallow sites.

\section{Amaurolithus tricorniculatus Zone (NN12)}

Definition. Interval from the last occurrence of Discoaster quinqueramus to the first occurrence of Ceratolithus rugosus.

Remarks. C. acutus has its first, and Triquetrorhabdulus rugosus has its last, occurrence in this zone.

Typical $D$. surculus becomes quite common within and above this zone at our sites.

\section{Ceratolithus rugosus Zone (NN13)}

Definition. Interval from the first occurrence of Ceratolithus rugosus to the first occurrence of Discoaster asymmetricus.
Remarks. The boundary between this zone and the next higher zone is sometimes difficult to recognize because a few specimens resembling Discoaster asymmetricus may be found lower. Typically, however, $D$. asymmetricus is common only in its nominate zone and above.

Some five-rayed discoasters found in the NN10 and NN11 zonal interval are very similar to $D$. asymmetricus of the Pliocene; some, however, have vestigial bifurcation of rays like $D$. calcaris and are here included with $D$. calcaris.

\section{Discoaster asymmetricus Zone (NN14)}

Definition. Interval from the first occurrence of Discoaster asymmetricus to the last occurrence of Amaurolithus tricorniculatus.

Remarks. $A$. delicatus instead of $A$. tricorniculatus is used to define the top of this zone because the latter species is very rare at the studied sites.

\section{Reticulofenestra pseudoumbilica Zone (NN15)}

Definition. Interval from the last occurrence of Amaurolithus tricorniculatus to the last occurrence of Reticulofenestra pseudoumbilica s. ampl.

Remarks. This zone is easily recognized in the studied sites. In the upper part, small specimens of $R$. pseudoumbilica are typical. The large $R$. pseudoumbilica becomes extinct somewhat earlier than the smaller one. Sphenolithus abies (S. neoabies included) has its last occurrence in the upper part of Zone NN15, whereas Pseudoemiliania lacunosa has its first occurrence in the uppermost part of this zone.

\section{Discoaster surculus Zone (NN16)}

Definition. Interval from the last occurrence of Reticulofenestra pseudoumbilica to the last ocurrence of Discoaster surculus.

Remarks. D. tamalis and $D$. asymmetricus have their last occurrences within this zonal interval.

\section{Discoaster pentaradiatus Zone (NN17)}

Definition. Interval from the last occurrence of Discoaster surculus to the last occurrence of $D$. pentaradiatus.

Remarks. This zone is very thin. It was not recognized at several of the sites studied.

\section{Discoaster brouweri Zone (NN18)}

Definition. Interval from the last occurrence of Discoaster pentaradiatus to the last occurrence of $D$. brouweri.

\section{Pseudoemiliania lacunosa Zone (NN19)}

Definition. Interval from the last occurrence of Discoaster brouweri to the last occurrence of Pseudoemiliania lacunosa.

Remarks. Ceratolithus rugosus, Calcidiscus macintyrei, and $\mathrm{Hel}$ icosphaera sellii have their last occurrences, whereas Gephyrocapsa caribbeanica and $G$. oceanica have their first occurrences in the lower part of this zone. Coccolithus pelagicus is greatly reduced in number at the base of this zone.

Calcidiscus macintyrei is much more common at the deeper sites than at the shallower sites.

\section{Gephyrocapsa oceanica Zone (NN20)}

Definition. Interval from the last occurrence of Pseudoemiliania lacunosa to the first occurrence of Emiliania huxleyi.

\section{Emiliania huxleyi Zone (NN21)}

Definition. Interval with Emiliania huxleyi.

Remarks. The boundary between Zones NN20 and NN21 is difficult to determine because $E$. huxleyi is too small to be identified with the light microscope with certainty. The recognition of the upper part of this zone is, however, much easier because the nominal species is extremely abundant there.

\section{SUMMARY OF SITES}

The Neogene and Quaternary calcareous nannofossil assemblages recovered during DSDP Leg 74 are discussed 
in detail as follows: each hole is considered separately, and the basis for biostratigraphic age assignments is documented. Range charts are presented for all holes.

Hole $525\left(29^{\circ} 04.24^{\prime} \mathrm{S}, 02^{\circ} 59.12^{\prime} \mathrm{E}\right.$; water depth: $2467 \mathrm{~m}$ )

Only one surface core, from 0-3.6 meters, was recovered at Hole 525. The core catcher sample from 3.6 meters sub-bottom contains abundant Pseudoemiliania lacunosa with common Helicosphaera carteri and Calcidiscus leptoporus. Other few to rare species are small Gephyrocapsa spp., Rhabdosphaera clavigera, Syracosphaera pulchra, Craspedolithus declivus, Scapholithus fossilis, and Ceratolithus rugosus. Gephyrocapsa oceanica may be present; however, no specimens with a complete bridge were found. This assemblage indicates the early Pleistocene $P$. lacunosa Zone (NN19). No checklist was prepared for this hole because of duplication of the cored interval at Hole 525A.

Hole 525A $\left(29^{\circ} 04.24^{\prime} \mathrm{S}, 02^{\circ} 59.12^{\prime} \mathrm{E}\right.$;

water depth: $2467 \mathrm{~m}$ )

Hole 525A was drilled with conventional rotary coring. Sediments were not continuously cored above 165.1 meters sub-bottom. Table 2 represents the nannofossil distribution in this hole. The nannofossil biostratigraphy is here given for the NN3 through NP25 zonal interval. Nannofossil distribution younger than the NN3 zone for Hole 525A may be compared with that for the nearby Hole 525B given in Table 3.

Quaternary sediments were recognized only in Core 1. The core-catcher sample contains essentially the same assemblage as that found in Sample 525-1,CC of Hole 525 and is assigned to Zone NN19 of the early Pleistocene. The only difference is that most of the Gephyrocapsa species found in this core catcher sample have a complete bridge.

Core 2 has no recovery.

Cores 3 and 4 are early Pliocene in age (Zones NN13NN12), based on the presence of Reticulofenestra pseudoumbilica, Sphenolithus abies, Amaurolithus delicatus, A. primus, A. tricorniculatus, Ceratolithus rugosus, and $C$. acutus and the absence of $A$. amplificus and Discoaster quinqueramus. Cores 5 and 6 are assigned to Zone NN11 of the late Miocene, on the basis of the very rare occurrence of $D$. quinqueramus. It is worth mentioning that Core 5 contains Amaurolithus species without $D$. neohamatus, whereas Sample 525A-6,CC contains $D$. neohamatus without Amaurolithus species.

Core 7 through Sample 525A-8-2, 40-41 cm belongs to the middle Miocene Zone NN6, based on the abundant occurrence of Cyclicargolithus floridanus with some $D$. deflandrei s. ampl. and Coronocyclus nitescens and on the absence of Sphenolithus heteromorphus. Sample 525A-8-2, 40-41 cm through Sample 525A-9,CC are assigned to the middle Miocene Zone NN5, based on the common presence of $S$. heteromorphus with some $D$. variabilis $\mathrm{s}$. ampl. and rare $D$. exilis.

Core 10 through Sample 525A-11-1, 40-41 cm belongs to the early Miocene Zone NN4, based on the presence of $S$. heteromorphus with common $D$. deflan- drei and without $D$. variabilis and $D$. exilis. The two very rare occurrences of $S$. belemnos in the lower part of this interval are interpreted as due to reworking or mixing during coring. Samples 525A-11-2, 40-41 cm through $525 \mathrm{~A}-11-4,40-41 \mathrm{~cm}$ are typical of the early Miocene Zone NN3 because of the common occurrence of $S$. belemnos. Samples 525A-11-5, 40-41 cm through 525A$13-4,40-41 \mathrm{~cm}$ are assigned to the early Miocene Zone NN2, based on the presence of Discoaster sp. aff. D. druggii and the absence of S. belemnos. Sphenolithus sp. aff. $S$. belemnos, however, might be present in this interval.

Samples 525A-13-5, 40-41 cm through 525A-17-2, $40-41 \mathrm{~cm}$ belong to the early Miocene Zone NN1. In this zonal interval, several biological events occur: Zygrhablithus bijugatus becomes extinct in Sample 525A-16,CC; Dictyococcites bisectus, in Sample 525A-16-1, 40-41 $\mathrm{cm}$; and $D$. dictyodus, in 525A-15-6, 40-41 cm. Sphenolithus capricornutus and $S$. delphix have very short ranges in the lower part of this zone. Only a single specimen of Helicosphaera recta was found in Sample 525A$15-7,40-41 \mathrm{~cm}$. It is uncertain whether it is in place or is a redeposited specimen.

Sphenolithus ciperoensis last occurs in 525A-17,CC, and this point is taken to mark the top of the Oligocene.

The preservation of calcareous nannofossils in Hole 525A in general is moderate. Dissolution and recrystallization increase downhole. Discoasters in Cores 3 through 6 are moderate in preservation; however, they are poor from Core 7 downward. Overgrowth has destroyed many species characters of discoasters, which makes species identification difficult or impossible.

Hole 525B $\left(2^{\circ} 04.24^{\prime} \mathrm{S}, 02^{\circ} 59.12^{\prime} \mathrm{E}\right.$; water depth: $2467 \mathrm{~m}$ )

Hole 525B was drilled with hydraulic piston coring. Sediments were continuously cored from 0 to 209.4 meters sub-bottom to compensate for the coring gap in Hole 525A. Table 3 represents the Neogene and Quaternary nannofossil distribution in this hole.

The youngest calcareous nannofossil zone, NN21, of the late Pleistocene was recognized in Samples 525B-1$1,20-32 \mathrm{~cm}$ and $525 \mathrm{~B}-1-1,80-82 \mathrm{~cm}$, based on the abundant occurrence of Emiliania huxleyi together with Gephyrocapsa oceanica. The next zone, NN20, of the late Pleistocene was encountered in Sample 525B-1-2, 30-32 cm. Then the first downhole occurrence of Pseudoemiliania lacunosa in 525B-1-2, 80-82 cm places this sample at the top of early Pleistocene Zone NN19.

Samples 525B-1,CC and 525B-2-1, 60-61 cm are dominated by small Gephyrocapsa with rare $G$. oceanica and G. caribbeanica. According to Gartner (1977), this assemblage belongs to the small Gephyrocapsa acme interval which is in the middle part of the Zone NN19. The highest occurrence of Helicosphaera sellii is in Sample 525B-2-2, 60-61 cm. Next to it, the highest occurrence of Calcidiscus macintyrei is in 525B-2-3, 60-61 cm, and the lowest occurrence of typical $G$. oceanica and $G$. caribbeanica is in 525B-2,CC. The early Pleistocene calcareous nannofossil assemblages in Hole 525B are essentially the same as those in Holes 525 and 


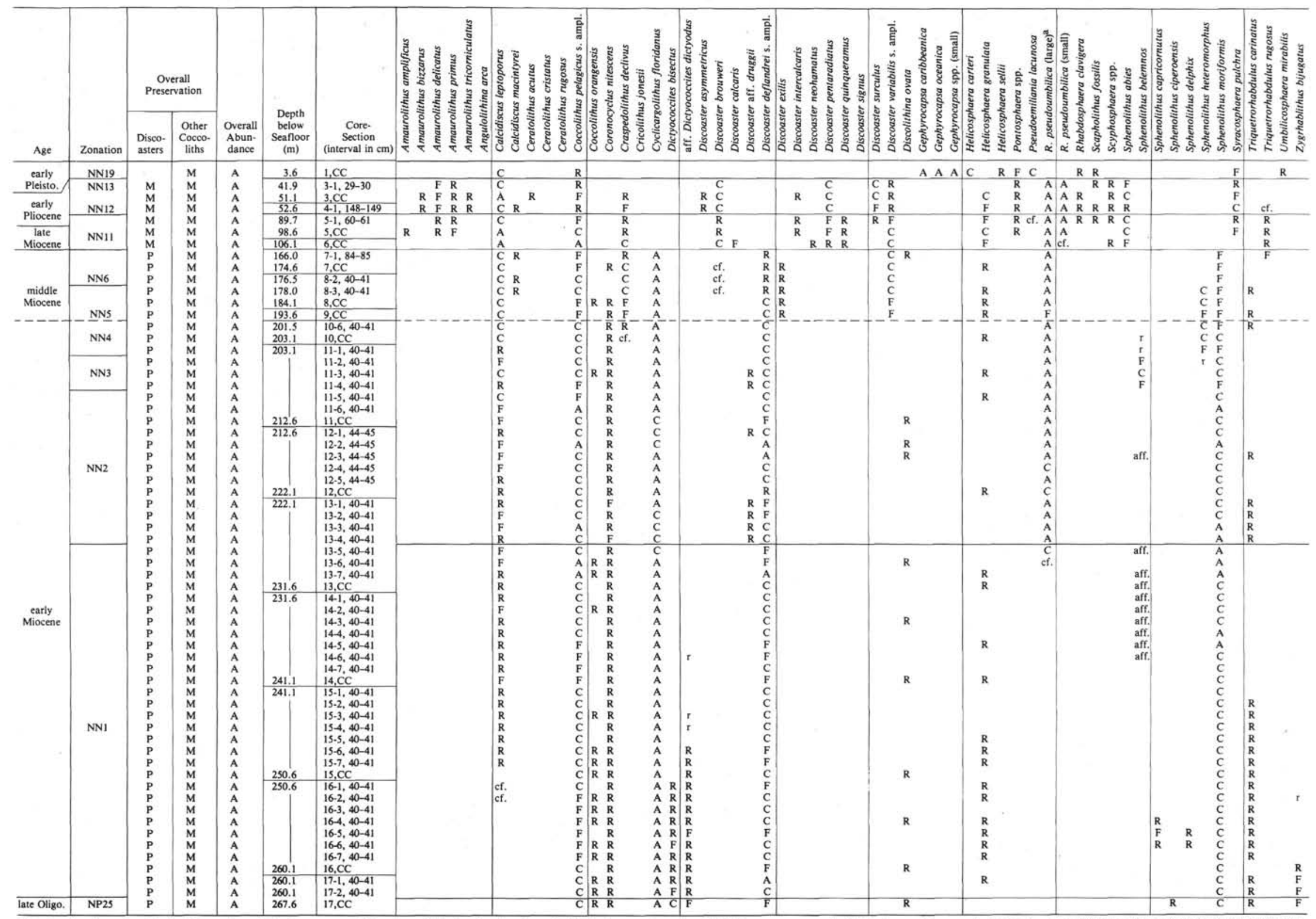

Note: For abundance, $\mathrm{A}=$ abundant, 10 specimens/field; $\mathrm{C}=$ common, $1-10$ specimens $/$ field; $\mathrm{F}=$ few, 1 specimen/1-10 fields; $\mathrm{R}=\mathrm{rare}, 1$ specimen $/ 10$ fields; $\mathrm{r}=$ very rare, probably due to reworking or contamination (counts at $1000 \times$ magnification). The following species were

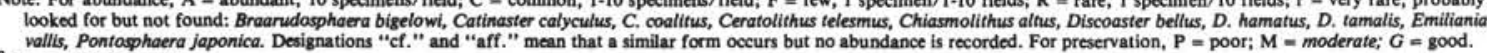


525A. Very rare Discoaster brouweri found in this interval are interpreted as reworked.

Typical, well-preserved $D$. brouweri with slender long arms is first encountered in Sample 525B-3-2, 53-54 cm, which places this sample at the top of Zone NN18 of the late Pliocene. Next, common D. pentaradiatus, the index species for Zone NN17 of the late Pliocene, is recorded in 525B-4-2, 65-66 cm. Zone NN17 represents a very short time interval, because $D$. surculus, the index species of Zone NN16 of the late Pliocene, is in Sample 525B-4-3, 65-66 cm. Discoaster asymmetricus and D. tamalis have their highest occurrences in Zone NN16 of Hole 525B. Also, typical $H$. carteri gradually gives way downward to a robust form, $H$. granulata, in this interval.

Typical Reticulofenestra pseudoumbilica (small and large forms) abundantly occurs for the first time in Sample 525B-5-2, 81-83 cm, which places this sample in the top of Zone NN15 of the early Pliocene. Within Zone NN15, the highest occurrence of Sphenolithus abies is found in 525B-7-2, 39-40 cm, whereas the lowest occurrence of Pseudoemiliania lacunosa is traced down to Sample 525B-7-3, 39-40 cm. Helicosphaera sellii is no longer found below this zone in Hole 525B, but $D$. variabilis is continuously recorded in the lower part of this zone and downward.

Amaurolithus delicatus first appears in Sample 525B$8-3,3-4 \mathrm{~cm}$, which places this sample at the top of Zone NN14 of the early Pliocene. Amaurolithus delicatus and A. primus are the most common species of the Amaurolithus group in this interval and down to the upper Miocene. Typical specimens of $A$. tricorniculatus are very rare. The birefringent Ceratolithus rugosus is traced down to 525B-12-1, 10-11 cm, which places this sample at the base of Zone NN13 of the early Pliocene. The NN13/NN14 boundary cannot be defined with certainty in Hole 525B, because the NN14 index species, D. asymmetricus, consistently occurs downward. Discoaster decorus is found sporadically within the NN13/NN14 zonal interval and down to Zone NN11 of the late Miocene.

The interval between Samples 525B-12-1, 54-55 cm and $525 \mathrm{~B}-14-2,40-41 \mathrm{~cm}$ is assigned to Zone NN12 of the earliest Pliocene, based on the absence of both $C$. rugosus and $D$. quinqueramus. The highest occurrence of Triquetrorhabdulus rugosus is recorded in 525B-13$3,40-41 \mathrm{~cm}$, and $A$. bizzarus is found only in 525B-13-1, $40-41 \mathrm{~cm}$.

The highest occurrence of $D$. quinqueramus is traced up to Sample 525B-14-2, 100-101 cm, which places this sample at the top of Zone NN11 (i.e., the top of the upper Miocene). Aside from the index species, the calcareous nannofossil assemblages in the early Pliocene and the late Miocene are essentially the same. Discoaster brouweri, $D$. surculus, $D$. pentaradiatus, $D$. decorus, $D$. variabilis, and $D$. intercalcaris are quite common in these intervals. Although $D$. quinqueramus is very rare in the upper Miocene of Hole 525B, its occurrence is sufficiently consistent to outline its total range zone. Zone NN11 can further be divided into two parts. The upper part is characterized by the presence of $A$. delicatus and A. primus which is traced down to Sample
525B-23-2, 37-38 cm. The lower part is represented by the presence of $D$. neohamatus, which is traced up to the same sample. Amaurolithus amplificus has a very short range and is restricted to the upper part of Zone NN11. In the lower part of Zone NN11 and downward, slender yet giant $D$. brouweri ( $D$. neorectus type), together with large $D$. neohamatus and $D$. variabilis, are prominent.

The interval between Samples 525B-25-1, 36-37 cm and $525 \mathrm{~B}-28, \mathrm{CC}$ belongs to Zone NN10 of the late Miocene, based on the absence of both $D$. quinqueramus and $D$. hamatus. Discoaster variabilis, large $D$. neohamatus, and large, slender $D$. brouweri are still the major discoaster components in this zone. Minylitha convallis, which rarely occurs in the lower part of Zone NN11, becomes very abundant throughout the $\mathrm{NN} 10$ zonal interval. This species, according to Bukry (1973), commonly occurs in the middle-late Miocene transitional interval. A form of discoaster with five asymmetrical arms occurs sporadically throughout this interval and its overlying NN11 Zone. This form looks much like $D$. asymmetricus of the Pliocene. However, some specimens with better preservation show vestigial bifurcations. This form may be related to the five-rayed $D$. calcaris and should not be included in D. asymmetricus, with which it does not have a continuous range.

The interval between Samples 525B-29-1, 76-77 cm and 525B-32-2, 113-114 cm is included in Zone NN9 of the middle Miocene, based on the total range of $D$. hamatus. Minylitha convallis is still very abundant in the upper part of this zone. It quickly becomes rare downwards, however, and disappears in the lower part of this zone. Within the NN9 zonal interval, several biological events occur. The small $R$. pseudoumbilica are no longer observed within this zone; $D$. pentaradiatus is not recorded below Sample 525B-29-2, 76-77 cm; Catinaster calyculus first appears in 525B-30-1, 44-45 cm and $C$. coalitus in 525B-32-2, 113-114 cm. Besides D. hamatus, the major discoaster components in this zone are $D$. variabilis, $D$. brouweri, $D$. neohamatus, $D$. bellus, and $D$. calcaris. Some $D$. signus with long bifurcation of ray are also included in the discoaster assemblage. Discoaster calcaris, or transitional forms of $D$. calcaris and $D$. exilis, do not occur below Zone NN9, but $D$. neohamatus is traced down to Sample 525B-31,CC. Discoaster bellus, a form related to and associated with $D$. hamatus, has the same first occurrence as D. hamatus in 525B-32-2, 113-114 cm. Its highest occurrence, however, is traced up to Sample 525B-28,CC, the base of Zone NN10.

Samples 525B-32-3, 41-42 cm through 525B-33,CC belong to Zone NN8 of the middle Miocene, based on the presence of Catinaster species in the absence of $D$. hamatus. The absence of Catinaster species and of $C y$ clicargolithus floridanus places the interval between Samples 525B-34-1, 65-66 cm and 525B-36,CC in Zone NN7 of the middle Miocene. Below 525B-31,CC the preservation of discoasters suddenly becomes poor, most specimens being overgrown. In the NN7-NN8 zonal interval and downward, $D$. variabilis s. ampl. is the only dominant discoaster species. Moderately preserved $D$. 
Table 3. Nannofossil distribution at Hole 525, DSDP Leg 74.

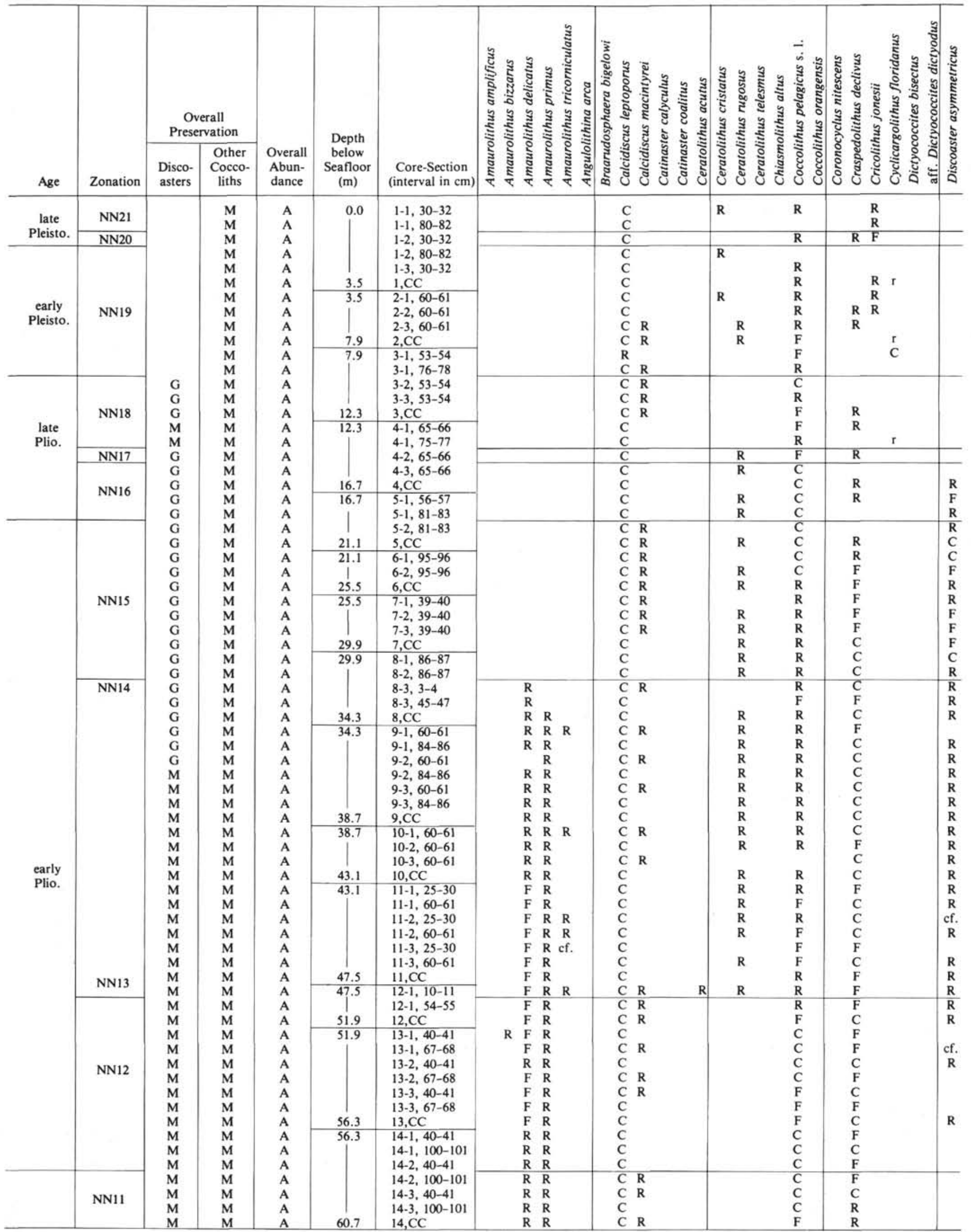


Table 3. (Continued).

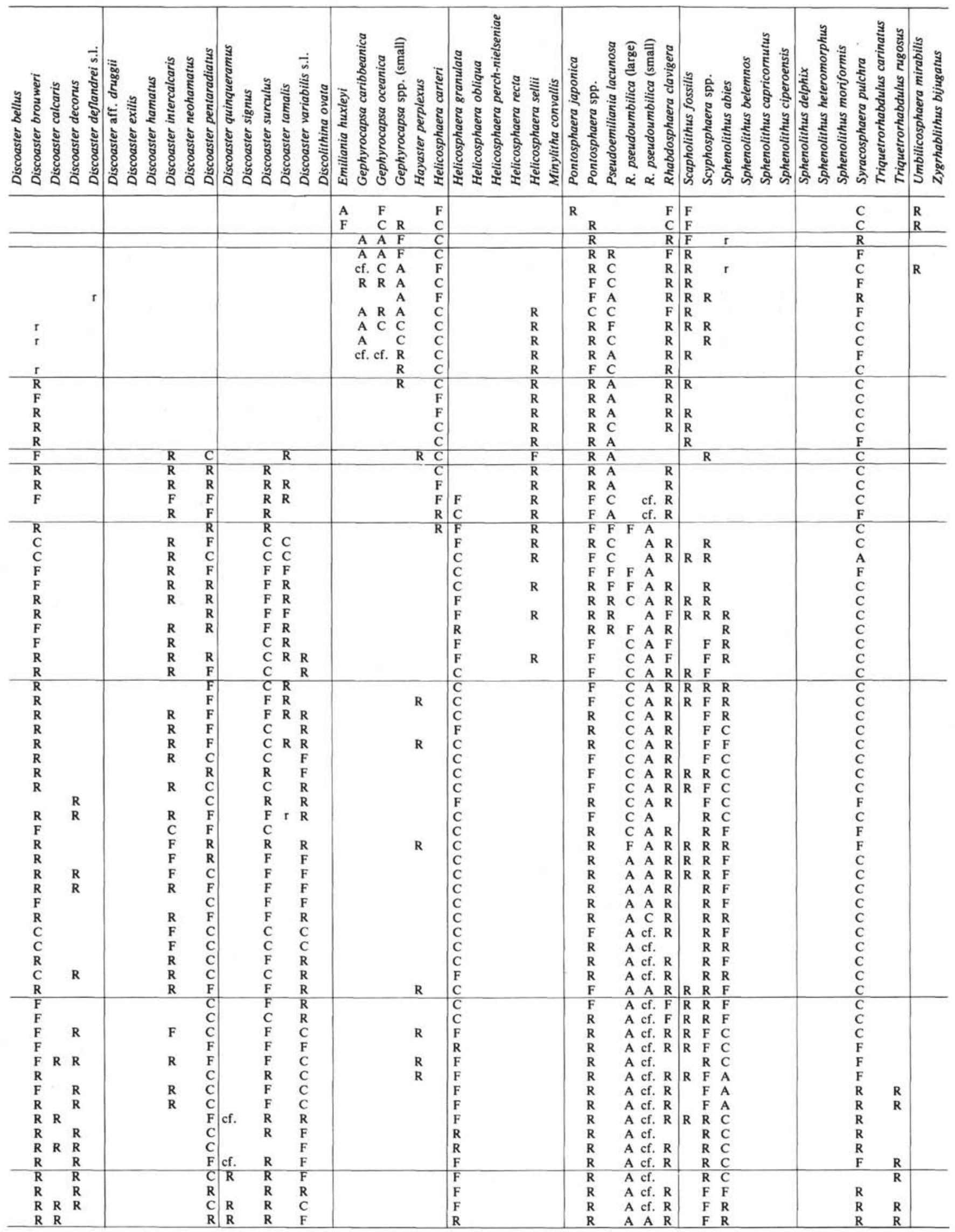


Table 3. (Continued).

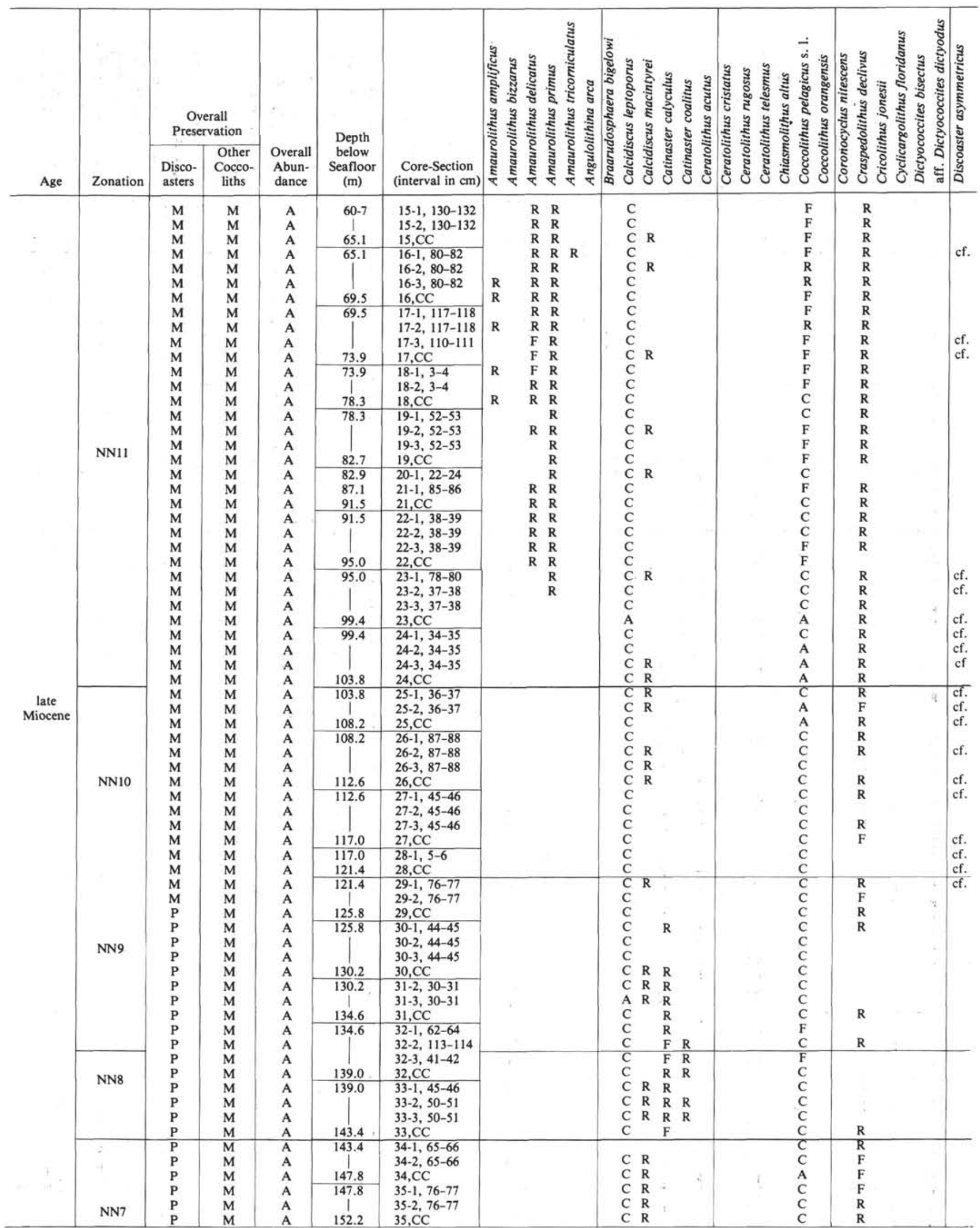


Table 3. (Continued).

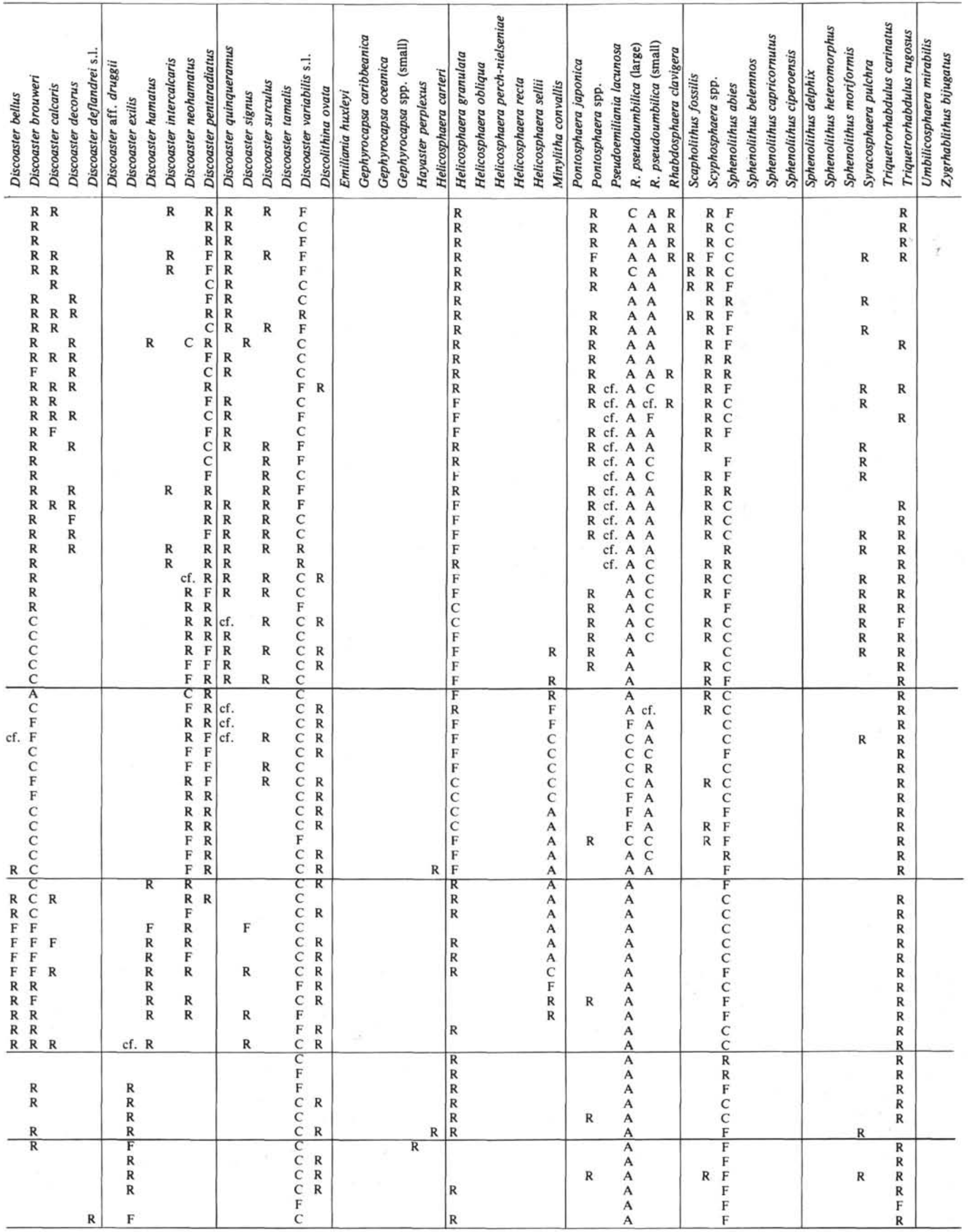


Table 3. (Continued).

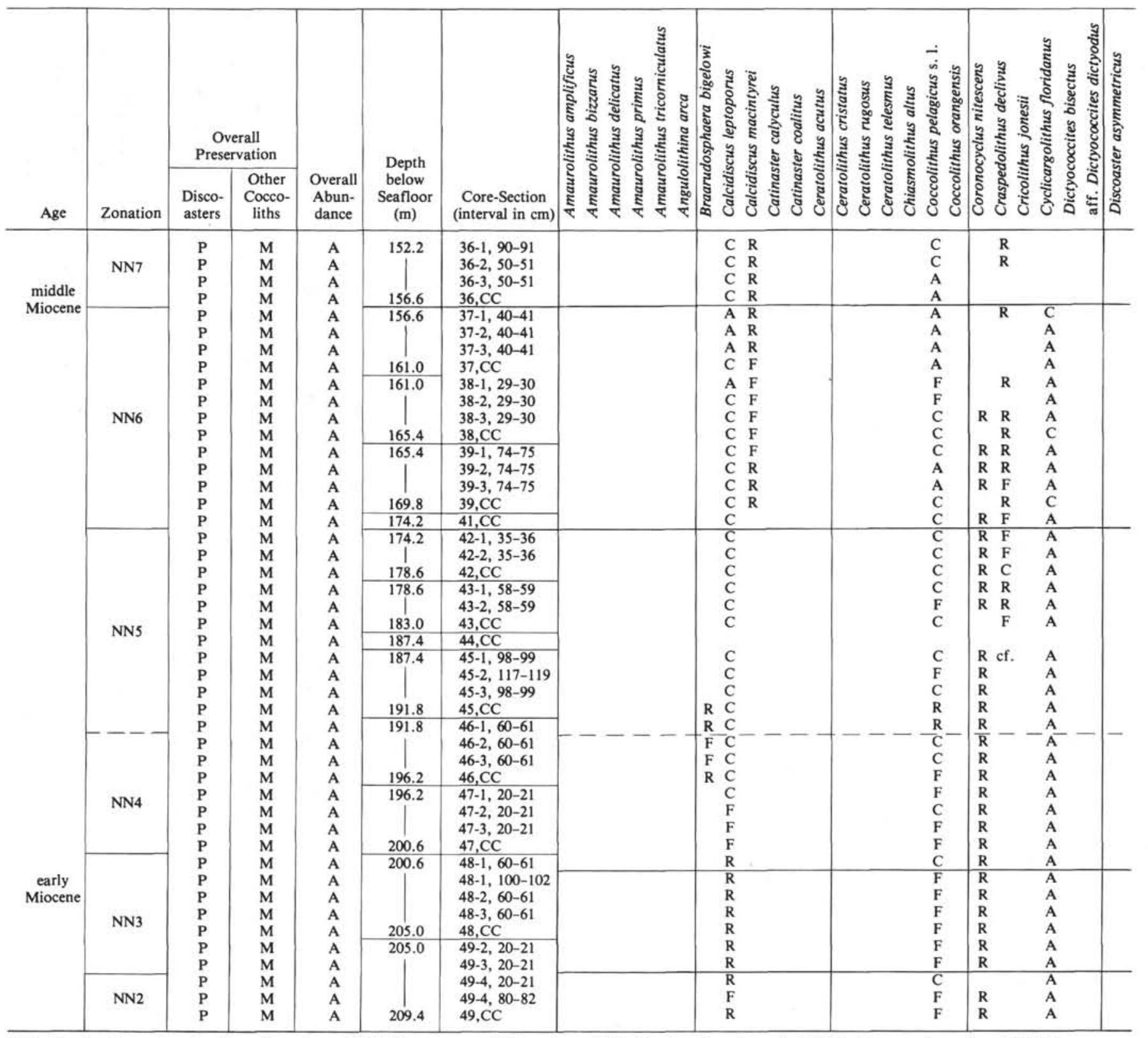

Note: For abundance, $\mathrm{A}=$ abundant, 10 specimens/field; $\mathrm{C}=$ common, $1-10$ specimens $/$ field $; \mathrm{F}=$ few, 1 specimen $/ 1-10$ fields; $\mathrm{R}=$ rare, 1 specimen $/ 10$ fields; $\mathrm{r}=$ very rare, probably due to reworking or contamination (counts at $1000 \times$ magnification). Designations "cf." and "aff." mean that a similar form occurs but no abundance is recorded. For preservation, $\mathrm{P}=$ poor; $\mathrm{M}=$ moderate; $\mathrm{G}=$ good. The dotted line indicates a zonal boundary of uncertainty.

${ }^{\text {a }} R=$ Reticulofenestra.

exilis is traced upward to Sample 525B-33-1, 45-46 cm, Zone NN8, whereas D. deflandre i is recorded up to 525B$35, \mathrm{CC}$ of the NN7 Zone. Because of poor preservation or environmental exclusion, typical D. kugleri, the index species for Zone NN7, was not observed in this hole.

The top of Zone NN6 of the middle Miocene is tentatively placed in Sample 525B-37-1, 40-41 cm, where the first downhole occurrence of $C$. floridanus is recorded. In the NN6 zonal interval, Coronocyclus nitescens has its highest occurrence in 525B-38-3, 29-30 cm, whereas Triquetrorhabdulus rugosus has its lowest occurrence in 525B-39,CC. Discoaster brouweri, D. signus, and Cy- clococcolithus macintyrei are no longer found below this zone.

The total range of $S$. heteromorphus, between Samples 525B-42-1, 35-36 cm and 525B-48-1, 60-61 cm, represents the NN5 and NN4 zonal intervals. Because of the absence of $H$. ampliaperta, the index species for Zone NN4, in Hole 525B, the NN5/NN4 boundary (i.e., the middle/early Miocene boundary) cannot be identified with certainty. Tentatively the NN5/NN4 boundary is placed between Samples 525B-46-1, 60-61 cm and $525 \mathrm{~B}-46-2,60-61 \mathrm{~cm}$. This is based on the fact that there is a significant discoaster assemblage change here. Above 
Table 3. (Continued).

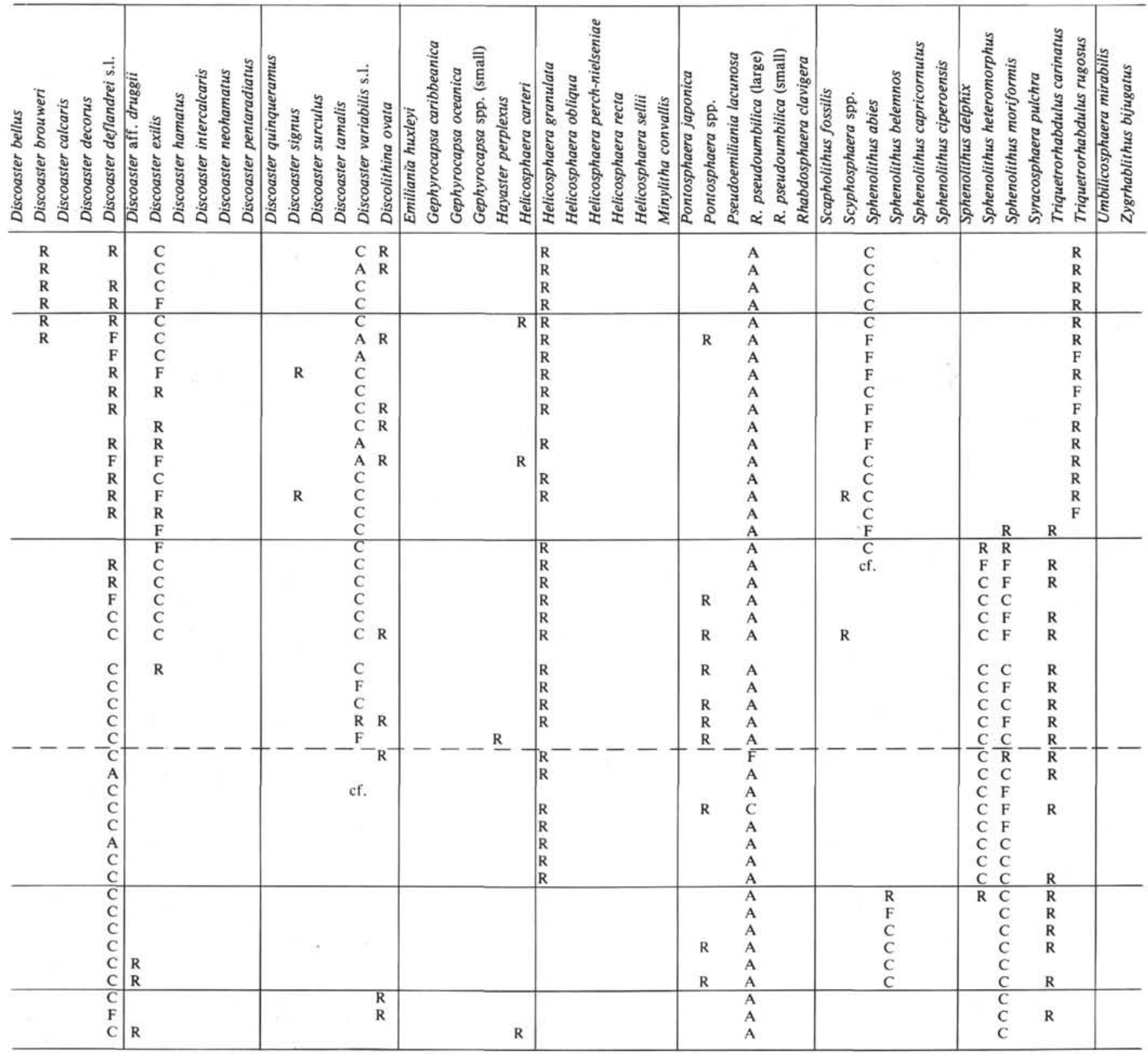

525B-46-1, 60-61 cm, D. variabilis is one of the dominant discoaster species, whereas below 525B-46-2, 60-61 $\mathrm{cm}$ it suddenly disappears. Discoaster deflandrei is then the only dominant discoaster in the assemblage. Rare specimens of a shallow-water or brackish-water form Braarudosphaera bigelowii are also recorded around the middle-early Miocene transition interval.

The interval between Samples 525B-48-1, 100-102 cm and $525 \mathrm{~B}-49-3,20-21 \mathrm{~cm}$ is assigned to Zone NN3 of the early Miocene, based on the total range of $S$. belemnos. The interval between 525B-49-4, 20-21 cm and 525B$49, \mathrm{CC}$ is Zone NN2 of the early Miocene in age, based on the absence of $S$. belemnos and the rare presence of
Discoaster sp. aff. D. druggii. Discoaster sp. aff. D. druggii, however, ranges up to the lower part of the NN3 Zone.

The preservation of the Neogene and Quaternary calcareous nannofossils at Hole 525B is moderate in general. Dissolution and recrystallization of placoliths increase downhole. The state of preservation of discoasters, however, fluctuates. Most discoasters recovered above Core 30 are moderately preserved. The best-preserved discoasters are found in the upper middle and lower upper Miocene interval. However, below Core 31 they are so poorly preserved that their diversity becomes very low in the lower middle and lower Miocene. 
Hole $526\left(30^{\circ} 07.36^{\prime} \mathrm{S}, 0^{\circ} 08.28^{\prime} \mathrm{E}\right.$; water depth: $1054 \mathrm{~m}$ )

Site 526 was the shallowest site drilled during Leg 74 . Hole 526 was drilled with hydraulic piston coring. Only two cores were recovered in this hole, however. Samples 526-1-1, 100-102 cm through 526-2-1, 106-107 cm belong to NN20 Zone of the late Pleistocene. The assemblage includes common Gephyrocapsa oceanica, small Gephyrocapsa sp., Calcidiscus leptoporus, Helicosphaera carteri, Syracosphaera pulchra, and Rhabdosphaera clavigera and rare Coccolithus pelagicus, Cricolithus jonesii, Scapholithus fossilis, Umbilicosphaera mirabilis, Pontosphaera japonica, and other Pontosphaera sp. Redeposited coccoliths from the Pliocene, Miocene, and Oligocene were also recorded. These are Chiasmolithus altus, Cyclicargolithus floridanus, Coronocyclus nitescens, Dictyococcites bisectus, Discoaster deflandrei, Pseudoemiliania lacunosa, Reticulofenestra pseudoumbilica, and Sphenolithus abies. Core 2 has poor recovery. The core catcher sample from 6.3 meters sub-bottom contains indigenous $P$. lacunosa and is assigned to the NN19 Zone of the early Pleistocene.

The calcareous nannofossil preservation in Hole 526 is moderate to good. A check list of the nannofossil distribution of this hole is given in Table 4.

Hole 526A $\left(30^{\circ} 07.36^{\prime} \mathrm{S}, \mathrm{03}^{\circ} 08.28^{\prime} \mathrm{E}\right.$; water depth: $1054 \mathrm{~m}$ )

Hole 526A was drilled with hydraulic piston coring. Sediments were continuously cored from 28.0 meters sub-bottom down to 228.8 meters (late Eocene). The core recovery in this hole is very good. No significant hiatuses were recognized through the Neogene. However, the sedimentation rate seems not to be consistent during the Neogene, because some of the calcareous nannofossil zones in this hole are represented by rather short intervals. A check list of the Neogene calcareous nannofossil distribution of Hole 526A is given in Table 4.

Three calcareous nannofossil zones are recognized in Core 1. Sample 526A-1-1, 75-76 cm contains abundant Reticulofenestra pseudoumbilica (both small and large forms), without Amaurolithus species, and is assigned to the NN15 Zone of the early Pliocene. This sample also contains Sphenolithus abies, yet without Pseudoemiliania lacunosa. It is reasonable to place this sample in the lower part of Zone NN15. Sample 526A-1-2, 75$76 \mathrm{~cm}$ belongs to Zone NN14 of the early Pliocene, based on the occurrence of both A. delicatus and Discoaster asymmetricus. Amaurolithus delicatus has its highest, and $D$. asymmetricus has its lowest, occurrence in this core sample. Samples 526A-1-3, 75-76 cm through 526A-2-2, 80-81 cm contain Ceratolithus rugosus without $D$. asymmetricus and therefore belong to the early Pliocene Zone NN13.

The interval between $562 \mathrm{~A}-2-3,80-81 \mathrm{~cm}$ and $526 \mathrm{~A}-$ $5-1,85-86 \mathrm{~cm}$ is included in the earliest Pliocene Zone NN12 based on the absence of $C$. rugosus and $D$. quinqueramus. Typical $A$. tricorniculatus is extremely rare in the early Pliocene of Hole 526A; it is found only in Sample 526A-2,CC. Triquetrorhabdulus rugosus has its highest occurrence in Sample 526A-4-3, 15-16 cm in this zone.

Again, the Pliocene/Miocene boundary is not easily recognized in Hole 526A, because $D$. quinqueramus, the index species for the late Miocene Zone NN11, is very rare. After a long search it was found that $D$. quinqueramus consistently occurs between Samples 526A-5-2, $85-86 \mathrm{~cm}$ and 526A-9,CC. This interval is therefore assigned to Zone NN11. As in Hole 525B, typical $A$. amplificus is restricted to the upper part of this zone. The occurrence of $A$. delicatus and $A$. primus, on the other hand, is traced down to Sample 526A-7,CC, where the highest occurrence of $D$. neohamatus is recorded. Typical Helicosphaera granulata gradually become more important than $H$. carteri in the late Miocene of Hole 526A. In fact, the two species are very difficult to differentiate during the late Miocene and early Pliocene. They could be the same taxon in different states of preservation. Also, in the lower part of this zone, Minylitha convallis occurs abundantly below Sample 526A$8, \mathrm{CC}$.

The interval between 526A-10-1, 103-104 $\mathrm{cm}$ and $526 \mathrm{~A}-12-3,25-26 \mathrm{~cm}$ is attributed to the late Miocene Zone NN10, based on the absence of $D$. quinqueramus and $D$. hamatus. This interval is also characterized by abundant $M$. convallis, common $D$. neohamatus, and common $D$. brouweri with long slender rays $(D$. rectus type). The highest occurrence of $D$. bellus is traced up to Sample 526A-11-3, 30-31 cm in this zone. As in Hole $525 \mathrm{~B}$, the same form of discoaster with five asymmetrical arms occurs sporadically within the late Miocene NN10-NN11 zonal interval of this hole.

The interval between 526A-12,CC and 526A-14,CC belongs to the middle Miocene Zone NN9, based on the total range of $D$. hamatus. Several biological events occur within this zonal interval, and the pattern of succession of these events is comparable to that recorded in Hole 525A. Minylitha convallis is still very abundant in the upper part of this zone, quickly becomes rare downward, and disappears in Sample 526A-14-2, 20-21 cm; the small $R$. pseudoumbilica are no longer observed within this zonal interval; the lowest occurrence of $D$. pentaradiatus is traced down to $526 \mathrm{~A}-12, \mathrm{CC} ; D$. neohamatus extends a little farther down but disappears above the first occurrence of $D$. hamatus; rare $D$. signus are observed within this zone, and Catinaster calyculus has its highest occurrence in Sample 526A-13,CC. However, $D$. bellus, a form related to and associated with $D$. hamatus, extends down to Zone NN8 in this hole.

Sample 526A-15-1, 26-27 cm through 526A-15,CC is included in Zone NN8 of the middle Miocene, based on the presence of $C$. calyculus and the absence of $D$. hamatus. Catinaster coalitus, the designated index species for Zone NN8, is very rare in this hole. Next below the absence of both C. calyculus and Cyclicargolithus floridanus places the interval between Samples 526A-16-1, $42-43 \mathrm{~cm}$ and $526 \mathrm{~A}-18-3,50-51 \mathrm{~cm}$, into Zone NN7 of the middle Miocene. As in Hole 525B, the preservation of discoasters becomes poor in the upper part of the middle Miocene. Discoaster brouweri s. ampl. is no longer found below the NN8 zonal interval. The over- 
grown $D$. variabilis becomes the only dominant discoaster species in the lower part of the middle Miocene. The first downhole occurrence of $D$. deflandrei is recorded in the lower part of Zone NN7. Discoaster kugleri, the true index for Zone NN7, is not found in Hole 526A, however.

The top of the middle Miocene Zone NN6 is tentatively placed in Sample 526A-18,CC, where the first downhole occurrence of $C$. floridanus is recorded. Calcidiscus macintyrei is no longer recorded below this zone. Also in the NN6 zonal interval, Coronocyclus nitescens has its highest occurrence in 526A-19-3, 40-41 cm, whereas Triquetrorhabdulus rugosus has its lowest occurrence in 526A-18, CC.

Though no significant hiatus is found in the early middle, and early Miocene of Hole 526A, the sediment interval represented by Zone NN5 through Zone NN2 is very thin in this hole. The total range of $S$. heteromorphus places the interval between Samples 526A-20-3, $78-79 \mathrm{~cm}$ and $526 \mathrm{~A}-21-1,70-71 \mathrm{~cm}$, into Zones NN5 and NN4. Next, the total range of $S$. belemnos limits the interval between Samples 526A-21-2, 70-71 cm and $526 \mathrm{~A}-21, \mathrm{CC}$ to Zone NN3 of the early Miocene. In $526 \mathrm{~A}-22-1,85-86 \mathrm{~cm}, S$. belemnos is absent. The lowest occurrence of Discoaster sp. aff. D. druggii assigns this sample to Zone NN2 of the early Miocene.

Helicosphaera ampliaperta is absent and the NN5/ NN4 boundary (i.e., the middle/early Miocene boundary) is recognized in this hole by a sudden discoaster assemblage change recorded between Samples 526A-20,CC and 526A-21-1, 70-71 cm. In 526A-20,CC and above, D. variabilis is the only dominant discoaster species, whereas in 526A-21-1, 70-71 cm and below, no D. variabilis is observed. Discoaster deflandrei becomes the only dominant discoaster species. Helicosphaera obliqua occurs sporadically between 526A-20,CC and 526A-212, $70-71 \mathrm{~cm}$.

The long interval between Samples 526A-22-2, 85-86 $\mathrm{cm}$ and $526 \mathrm{~A}-30, \mathrm{CC}$ is assigned to Zone NN1 of the earliest Miocene, based on the absence of Discoaster sp. aff. D. druggii and S. ciperoensis. Sphenolithus sp. aff. $S$. belemnos ( $=S$. dissimilis?) appears sporadically within this zonal interval. In the upper part of this zone, R. pseudoumbilica and Calcidiscus leptoporus are still quite common. However, both forms become atypical downward and disappear in the lower part of this zone. In the lower part of this zone, Zygrahablithus bijugatus has its highest occurrence in Sample 526A-28-2, 44-45 $\mathrm{cm}$. Dictyococcites bisectus and $D$. aff. D. dictyodus, on the other hand, are not found above 526A-28-3, 44-45 cm. Also $S$. delphix and $S$. carpricornutus have very short ranges and are restricted to the lower part of Zone NN1 in this hole.

The top of the Oligocene is placed in Sample 526A$31-1,57-58 \mathrm{~cm}$, where the highest occurrences of $H$. rec$t a$ and $S$. ciperoensis are recorded. In the late Oligocene of this hole, several new species are encountered. These are Chiasmolithus altus, Ericsonia fenestrata, and $H$. perch-nielseniae. Helicosphaera recta and $H$. perch-nielseniae are hemipelagic species. They are very rarely found at other sites of DSDP Leg 74. However, because
Hole 526A is the shallowest $(1054 \mathrm{~m})$, both forms sporadically occur in the upper Oligocene of this hole. Also Braarudosphaera bigelowii, a hemipelagic form, occurs fairly consistently in the late Oligocene and the earliest Miocene of this hole.

The preservation of the Neogene calcareous nannofossils recovered in Hole 526A is much the same as that in Hole 525B. Assemblages in general are moderately preserved. Dissolution and recrystallization of placoliths increase downhole. Discoasters are moderately preserved in the Pliocene and the uppermost Miocene. However, from the middle Miocene on they become so strongly overgrown that species identification is sometimes difficult.

\section{Hole 526B $\left(3^{\circ} 07.36^{\prime} \mathrm{S}, \mathbf{0 3}^{\circ} 08.28^{\prime} \mathrm{E}\right.$; water depth: $1054 \mathrm{~m}$ )}

Hole 526B was drilled with hydraulic piston coring. Sediments were continuously cored from 6.3 down to 28.3 meters sub-bottom. The main purpose of this hole was to recover the coring gap between Holes 526 and 526A. The calcareous nannofossil distribution of this hole is given in Table 4.

Samples 526B-1-1, 30-32 cm through 526B-3-1, 35$36 \mathrm{~cm}$ belong to the early Pleistocene Zone NN19, based on the consistent presence of Pseudoemiliania lacunosa. Gephyrocapsa oceanica and $G$. caribbeanica are abundant in this interval, except in the lowest part, in 526B3-1, 35-36 cm. Samples 526B-3-2, 35-36 cm through 526B-3,CC contain Discoaster brouweri and are assigned to the late Pliocene Zone NN18. No G. oceanica, G. caribbeanica, D. pentaradiatus, or $D$. surculus were observed in this short interval. Sample 526B-4-2, 20-21 cm through 526B-5,CC are included in the early Pliocene Zone NN15, based on the common and persistent occurrence of Reticulofenestra pseudoumbilica. Because of the common presence of $P$. lacunosa without Sphenolithus abies, this interval is no older than the upper part of Zone NN15. Zones NN17 and NN16 are apparently missing. It is uncertain whether they are absent because of a minor hiatus or because of too large a sampling interval.

The calcareous nannofossils in Hole 526B are moderately preserved.

\section{Hole $526 \mathrm{C}\left(30^{\circ} 07.36^{\prime} \mathrm{S}, 0^{\circ} 08.28^{\prime} \mathrm{E}\right.$; water depth: $1054 \mathrm{~m}$ )}

Hole 526C was drilled with conventional rotary coring. A short sediment interval was tentatively cored to determine the Pliocene-Miocene transition at Site $\mathbf{5 2 6 .}$ The calcareous nannofossil distribution for this hole is given on Table 4.

Samples 526C-1-1, $100 \mathrm{~cm}$ through 526C-1,CC belong to the upper part of the early Pliocene Zone NN15, based on the presence of Reticulofenestra pseudoumbilica and Pseudoemiliania lacunosa, without Sphenolithus abies and Amaurolithus sp. The sediments recovered in Core 1 probably are not in place because Core 1 has a poor recovery. Samples 526C-2-1, 42-43 cm through 526C-2-7, $40-42 \mathrm{~cm}$ have an early Pliocene Zone NN12 age, based on the absence of Discoaster asymmetricus, Ceratolith- 
Table 4. Nannofossil distribution at Hole 526, 526A, 526B, and 526C, DSDP Leg 74.

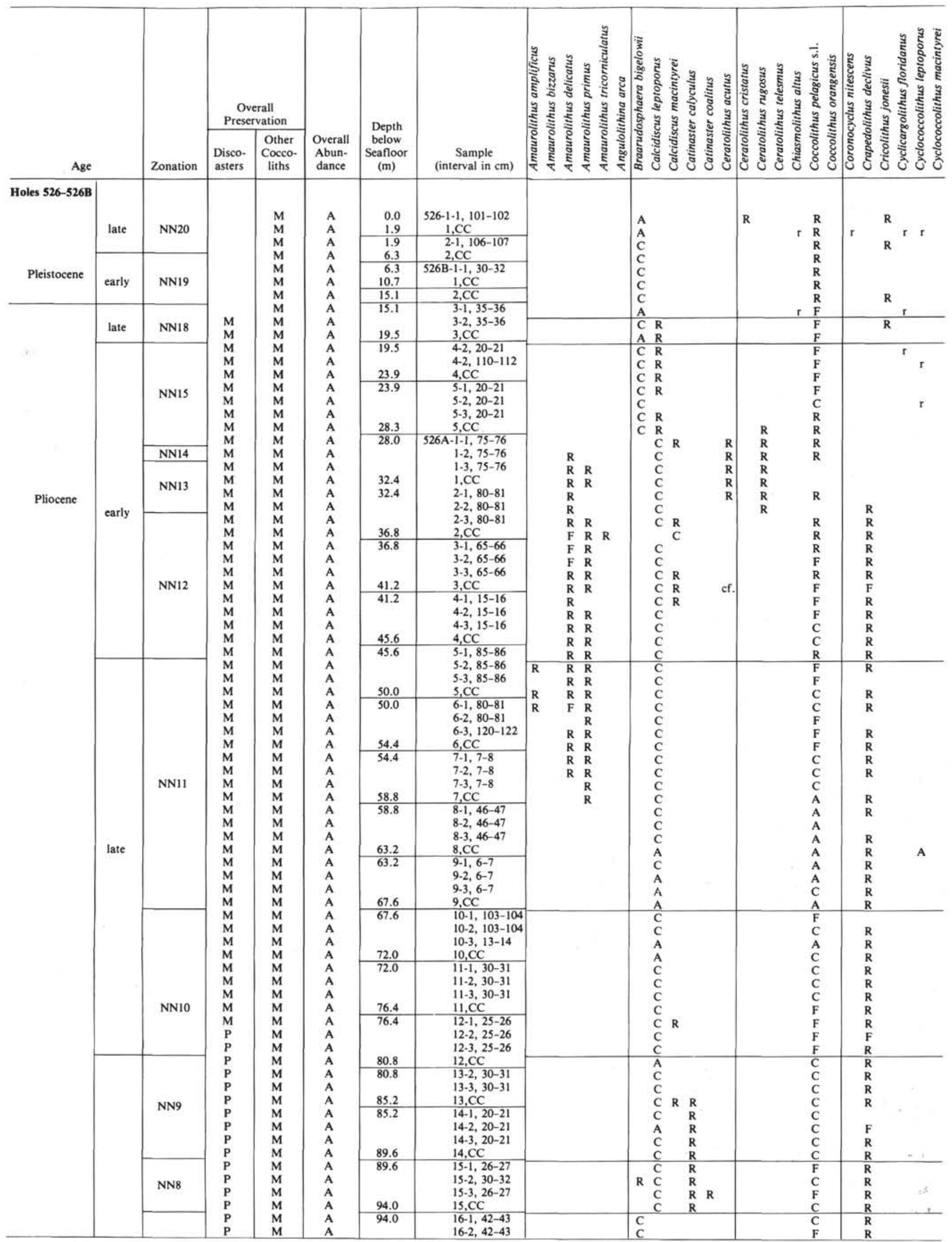


Table 4. (Continued).

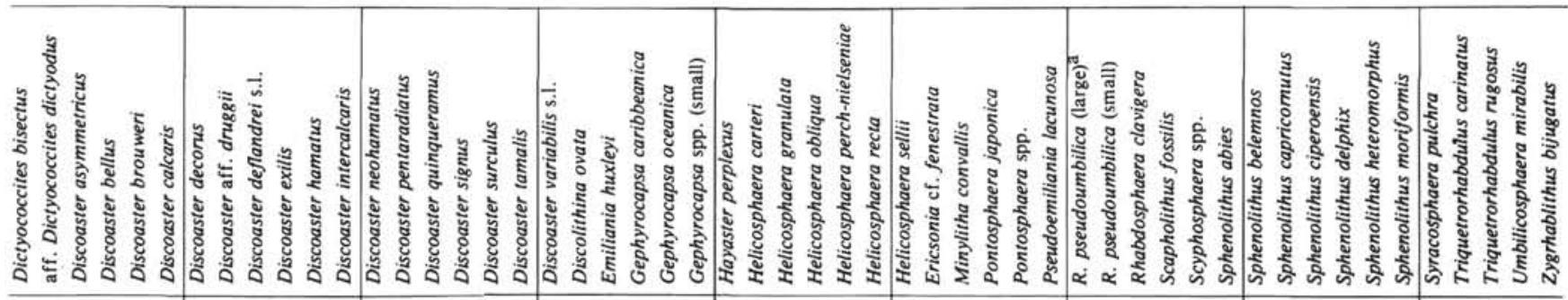

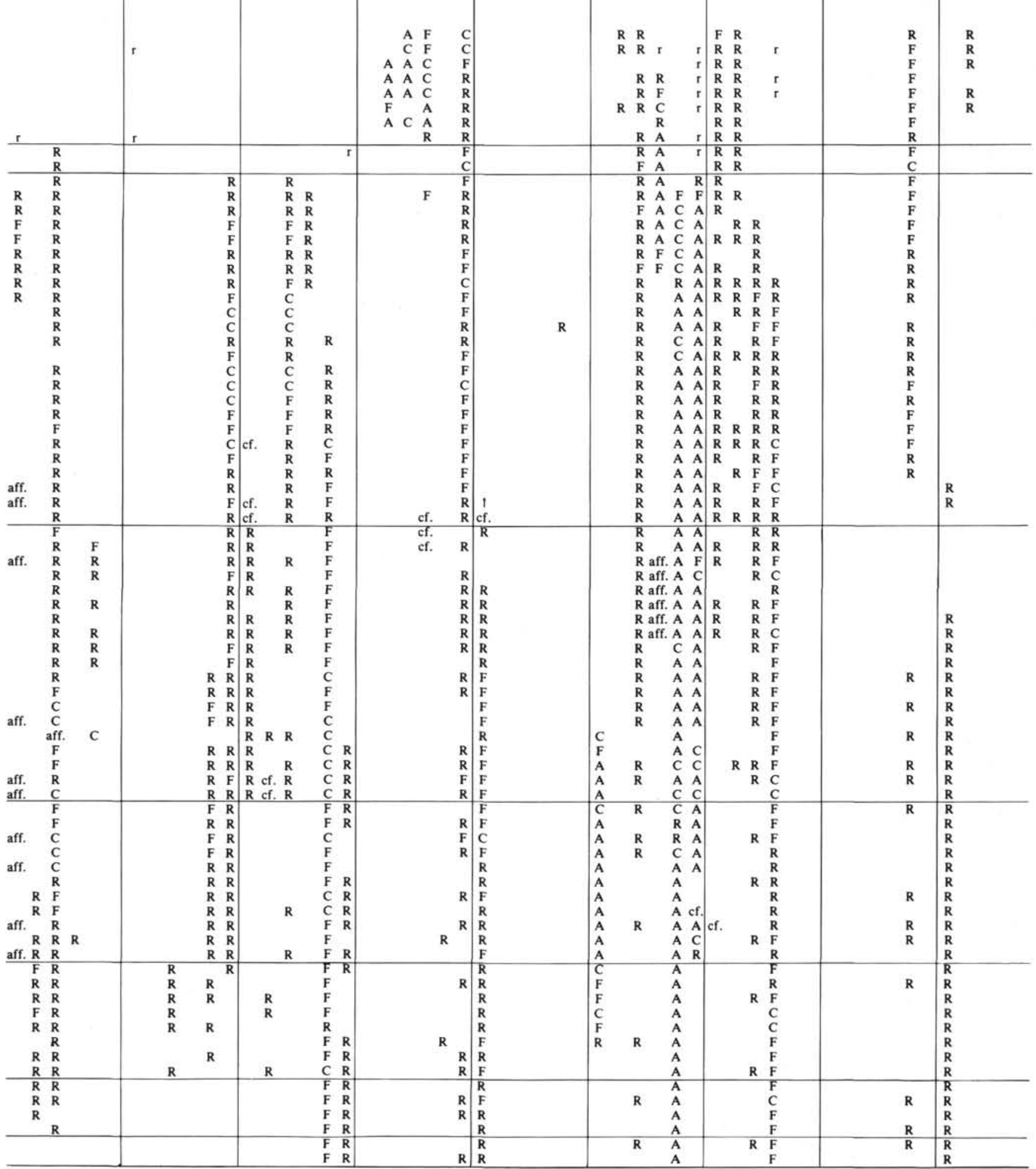


Table 4. (Continued).

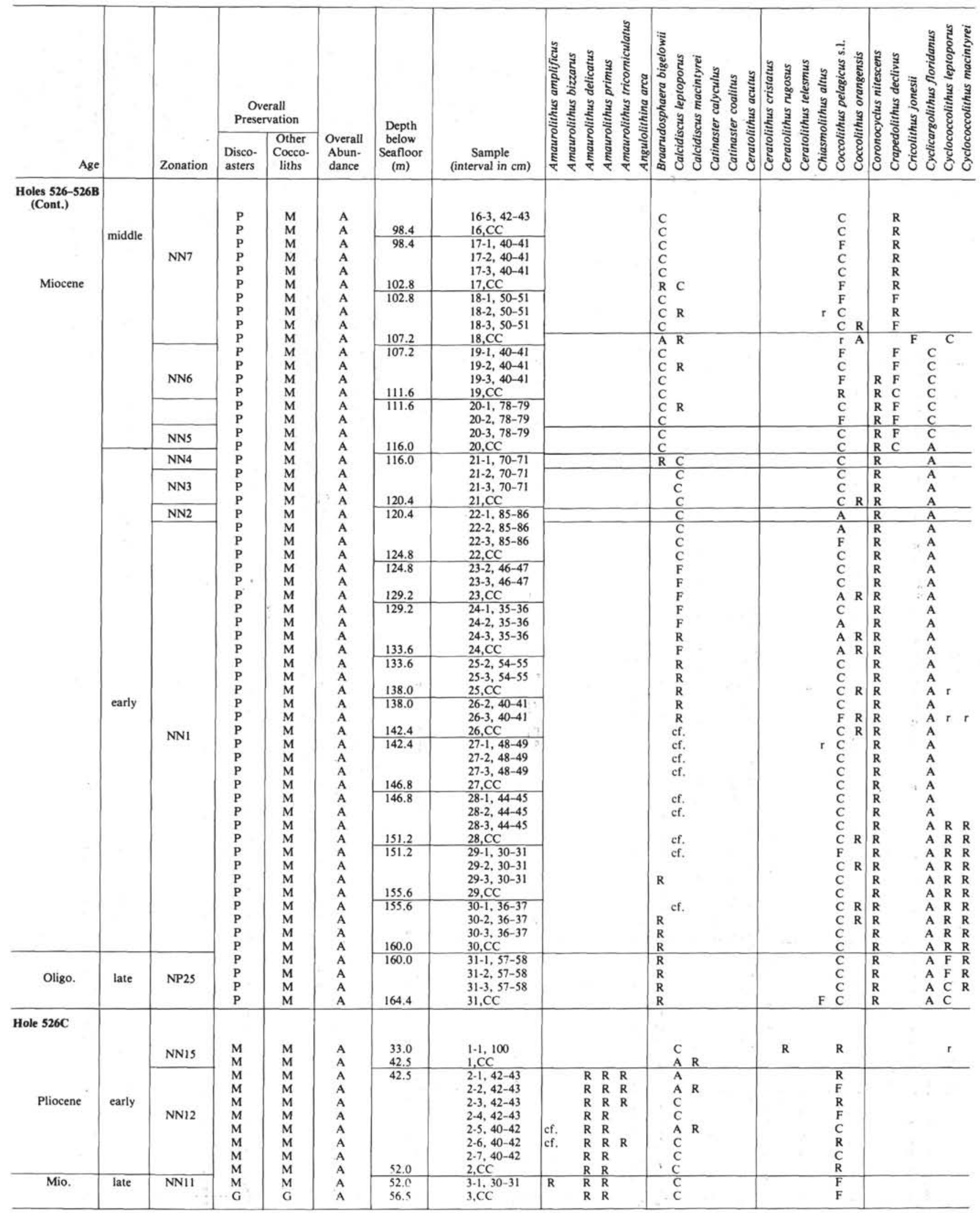

Note: For abundance, $\mathrm{A}=$ abundant, 10 specimens/field; $\mathrm{C}=$ common, $1-10$ specimens $/$ field; $\mathrm{F}=$ few, 1 specimen $/ 1-10$ fields; $R=$ rare, 1 specimen $/ 10$ fields; $\mathrm{r}=$ very rare, probably due to reworking or contamination (counts at $1000 \times$ magnification). Designations "cf." and "aff." mean that a similar form occurs but no abundance is recorded. For preservation, $\mathrm{P}=$ poor $; \mathrm{M}=$ moderate; $\mathrm{G}=$ good.

a $R=$ Reticulofenestra. 
Table 4. (Continued).

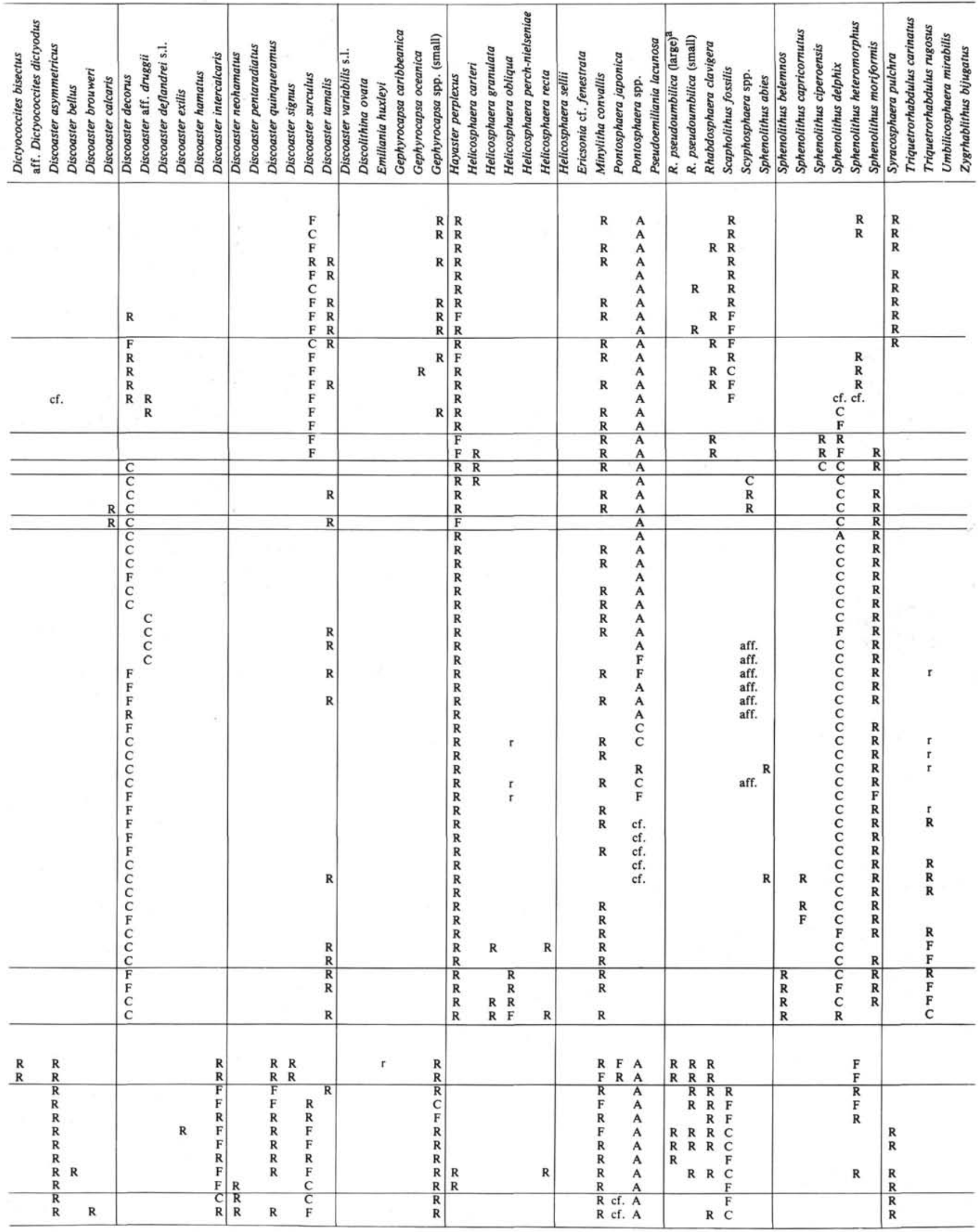


us rugosus, and $D$. quinqueramus. The assemblage recorded in this interval includes Amaurolithus delicatus, A. primus, Coccolithus pelagicus, Calcidiscus leptoporus, $D$. broweri, $D$. pentaradiatus, $D$. surculus, $D$. variabilis, Helicosphaera carteri, Pontosphaera sp., $R$. pseudoumbilica, Rhabdosphaera clavigera, Scapholithus fossilis, Scyphosphaera spp., Sphenolithus abies, and Syracosphaera pulchra. Triquetrorhabdulus rugosus has its highest occurrence in Sample 526C-2-4, 42-43 cm in this zonal interval.

Samples 526C-2,CC through 526C-3,CC contain $D$. quinqueramus and Amaurolithus sp. and belong to the upper part of the late Miocene Zone NN11. Rare A. amplificus are recorded only in 526C-3-1, 30-31 cm.

The calcareous nannofossils in Hole $526 \mathrm{C}$ are moderately preserved.

\section{Hole $527\left(28^{\circ} 02.49^{\prime} \mathrm{S}, 01^{\circ} 45.80^{\prime} \mathrm{E}\right.$; water depth: $\mathbf{4 4 2 8} \mathrm{m}$ )}

Site 527 is the deepest site drilled during Leg 74 . The hole was drilled with conventional rotary coring. Sediments were cored from the top down to the Maestrichtian of the Upper Cretaceous. A major depositional hiatus was encountered between Samples 527-13,CC and the top of Core 527-14. The missing section includes the lower part of the middle Miocene through the upper Oligocene. The calcareous nannofossils were studied above the major hiatus for this hole. The results are documented on Table 5. Special attention was given to the red clay interval just above the hiatus, where the calcareous nannofossil assemblages change very abruptly.

Samples 527-1-1, 29-31 cm through 527-2-1, 50-51 $\mathrm{cm}$ are Pleistocene in age. Because the entire interval contains common Pseudoemiliania lacunosa and Calcidiscus macintyrei with rare Helicosphaera sellii, it is included in the lower part of the earliest Pleistocene Zone NN19. Gephyrocapsa oceanica and G. caribbeanica are not recorded below 527-1-6, 29-31 cm. Calcidiscus macintyrei is rare at other shallower sites but is quite common at this deeper site.

The upper Pliocene is very thin in Hole 527. The late Pliocene Zone NN18 is recognized only in Sample 527$2, \mathrm{CC}$, based on the presence of Discoaster brouweri. Very rare and poorly preserved $D$. pentaradiatus in this sample are interpreted as reworked. Sample 527-3-1, $35-37 \mathrm{~cm}$ belongs to the late Pliocene Zone NN17, based on the indigenous occurrence of $D$. pentaradiatus without $D$. surculus. Coccolithus pelagicus becomes numerically significant in the nannofossil assemblage in this sample and downward. The interval between Samples $527-3-1,50-51 \mathrm{~cm}$ and $527-3-4,35-37 \mathrm{~cm}$ is included in the late Pliocene Zone NN16, based on the presence of D. surculus without Reticulofenestra pseudoumbilica. Discoaster tamalis has its highest occurrence in this zone in Hole 527.

The interval between Samples 527-3-4, 50-51 cm and $527-5, \mathrm{CC}$ is assigned to the early Pliocene Zone NN15, based on the common to abundant occurrence of $R$. pseudoumbilica. Pseudoemiliania lacunosa (typical and atypical) occurs throughout this zonal interval, whereas Sphenolithus abies has its highest occurrence in 527-5-3,
$50-51 \mathrm{~cm}$ in this zone. Also, $H$. carteri gradually gives way to $H$. granulata within this zonal interval.

The early Pliocene Zone NN14 is recognized only in Samples 527-6-1, 40-42 cm, where D. asymmetricus and Amaurolithus delicatus co-occur. The interval between $527-6-2,40-42 \mathrm{~cm}$ and $527-7-2,60-62 \mathrm{~cm}$ is included in the early Pliocene NN13-NN14 zonal interval, based on the presence of Ceratolithus acutus and Ceratolithus sp. cf. $C$. rugosus and on the absence of $D$. asymmetricus and $A$. amplificus. Zones NN13 and NN12 remain undifferentiated, because the lowest occurrence of the poorly preserved $C$. rugosus is difficult to determine in this interval. Typical A. tricorniculatus is not found, but $A$. bizzarus has its highest occurrence in Sample $527-7-2,60-62 \mathrm{~cm}$ in the lower part of this zonal interval.

Discoaster quinqueramus is missing in Hole 527. The Pliocene/Miocene boundary is tentatively located in Sample 527-7,CC, where the highest occurrence of $A$. amplificus is recognized. The interval between 527-7,CC and 527-12,CC contains $A$. primus, $A$. delicatus, and $A$. amplificus and belongs to the upper part of Zone NN11. Small $R$. pseudoumbilica and A. bizzarus do not extend down to the lower part of this interval. Below Core 11, red clay gradually becomes dominant. This corresponds to a minor assemblage change or, more specifically, to a preservational change. Well-preserved $D$. calcaris, $D$. variabilis, $D$. pentaradiatus, and $D$. brouweri become abundant, and dissolution and fragmentation of other coccoliths become more significant. Because of dissolution, neither $H$. granulata nor $H$. carteri is recorded below Core 11, and Sphenolithus abies is no longer present below Core 12 .

Core 13 has very good recovery, but the red clay is mostly barren of calcareous nannofossils. By selective sampling of light-colored calcareous mottles in the clay, common to abundant nannofossil assemblages were discovered. The entire Core 13 was therefore investigated with very closely spaced samples. The results reveal that these light-colored calcareous mottles scattered within the red clay are in-place materials. Core 13 contains several calcareous nannofossil zones. Section 527-13-1, top, to Section 527-13-1, 10 or $15 \mathrm{~cm}$ could belong to the lower part of Zone NN11. The lowest occurrence of $A$. primus is traced down to Section 527-13-1, $5 \mathrm{~cm}$, whereas the highest occurrence of $D$. neohamatus is recorded in 527-13-1, $10 \mathrm{~cm}$. Abundant Minylitha convallis occur throughout this interval and downward.

The NN10/NN11 boundary is difficult to determine. The interval between Sections 527-13-1, 15 to $20 \mathrm{~cm}$ and $527-13-1,50 \mathrm{~cm}$ could belong to the late Miocene Zone NN10. The assemblages are characterized by the enrichment of very well-preserved $D$. brouweri, $D$. neohamatus, $D$. calcaris, and $D$. variabilis, with rare $D$. bellus. Other important species present are exclusively solutionresistant forms, such as $R$. pseudoumbilica (large), Calcidiscus macintyrei, M. convallis, and Triquetrorhabdulus rugosus.

The interval between Sections 527-13-1, $63 \mathrm{~cm}$ and $527-13-5,44 \mathrm{~cm}$ is assigned to the middle Miocene Zone NN9, based on the total range of $D$. hamatus. The main 
components of the assemblage are not greatly different from those of the overlying Zone NN10. Discoaster bellus and the transitional form between $D$. calcaris and $D$. exilis become more significant in this zone. Discoaster neohamatus and $D$. pentaradiatus were no longer recovered below Section 527-13-1, $83 \mathrm{~cm}$. Well-preserved Catinaster coalitus and C. calyculus, on the other hand, first appear below Section 527-13-3, $83 \mathrm{~cm}$. Minylitha convallis is still abundant in the upper part of this zone but becomes rare and disappears in the lower part.

Sections 527-13-5, $66 \mathrm{~cm}$ to $527-13-6,129 \mathrm{~cm}$ are included in the middle Miocene Zone NN8, based on the occurrence of $C$. coalitus and $C$. calyculus and on the absence of $D$. hamatus. Well-preserved $D$. exilis and $D$. variabilis with rare $D$. brouweri are the main discoaster components in this interval. Typical $D$. kugleri, however, is not recorded.

Samples 527-13-7, 40-41 cm and 527-13,CC are barren of calcareous nannofossils. These represent the extreme of the red clay development. Next, the interval between 527-14-1, 28-29 cm and 527-14-3, 28-29 cm (or lower) contains an assemblage completely different. Among the species included are Coccolithus pelagicus, D. deflandrei, D. tanii, Dictyococcites bisectus, Sphenolithus moriformis, $H$. compacta, and $S$. predistentus, which indicates the early Oligocene Zone NP23. Because of reworking or mixing, rare species ranging from Eocene to earliest Oligocene were also observed in the upper part of this interval. They are $R$. umbilica, $D$. saipanensis, D. barbadiensis, and Cyclococcolithus formosus.

Except for the pure red clay interval, the abundant Neogene and Quaternary coccoliths and the Neogene discoasters recovered in Hole 527 are moderately to poorly preserved. Dissolution and fragmentation of placoliths and recrystallization of discoasters increase downhole. Below Core 11, where the red clay lithology becomes more dominant, dissolution and fragmentation increase. Species not resistant to dissolution disappear from the assemblages. The solution-resistant discoasters become enriched and appear well preserved. Core 13 represents the extreme of this phenomenon, because the well-preserved discoasters are so enriched that they dominate entire assemblages.

\section{Hole $528\left(28^{\circ} 31.49^{\prime} \mathrm{S}, 02^{\circ} 19.44^{\prime} \mathrm{E}\right.$; water depth: $3800 \mathrm{~m}$ )}

Hole 528 was drilled with conventional rotary coring. Core 1 sampled the topmost layer of the sediment. Continuous cores were taken from 122.0 meters sub-bottom. Quaternary and Neogene calcareous nannofossils were recovered in the six cores of this hole. A checklist of these Quaternary and Neogene calcareous nannofossils is given in Table 6 .

Core 1 is Pleistocene in age. Sample 528-1-1, 20-21 $\mathrm{cm}$ belongs to the late Pleistocene Zone NN20, based on the occurrence of Gephyrocapsa caribbeanica and $G$. oceanica and on the absence of Pseudoemiliania lacunosa. Then the interval between 528-1-2, $20-21 \mathrm{~cm}$ and $528-1, \mathrm{CC}$ is included in the early Pleistocene Zone NN19, based on the occurrence of P. lacunosa. Gephy- rocapsa caribbeanica and $G$. oceanica are abundant throughout this interval.

The interval between Core 2, top, and Section 528-3-1, $117 \mathrm{~cm}$ belongs to the NN5-NN4 zonal interval of the Miocene, based on the total range of Sphenolithus heteromorphus. The assemblage includes Coccolithus pelagicus, Cyclicargolithus floridanus, Calcidiscus leptoporus, Discoaster deflandrei, D. exilis, D. variabilis, $S$. heteromorphus, and S. moriformis. Discoaster exilis and other Discoaster species are common only above Sample 528-3-1, 23-24 cm, whereas $D$. deflandrei becomes consistently abundant below Section 528-3-1, 117 $\mathrm{cm}$. The NN5/NN4 boundary (i.e., the middle/early Miocene boundary) is therefore located in Section 5283-1 between $23-24 \mathrm{~cm}$ and $117 \mathrm{~cm}$. Within Zone NN5, sediments derived from slumping and reworking were recognized. The reworked species indicate an age ranging from the early Oligocene to middle Eocene. The assemblage recovered in Sample 528-2,CC is typical of the middle Eocene Zone NP14.

The interval between 528-3,CC and Section 528-4-3, $110 \mathrm{~cm}$ is included in the early Miocene Zone NN3, based on the total range of $S$. belemnos. Next below, the interval between Sections 528-4-3, $31 \mathrm{~cm}$ and 528-4-4, $67 \mathrm{~cm}$ is the early Miocene Zone NN2, based on the absence of typical S. belemnos and the rare presence of Discoaster sp. aff. $D$. druggii.

The long interval between Samples 528-4-5, $25-26 \mathrm{~cm}$ and 528-6,CC belongs to the early Miocene Zone NN1, based on the absence of Discoaster sp. aff. D. druggii and $S$. ciperoensis. In this zonal interval Calcidiscus leptoporus becomes atypical. It eventually disappears in the lower part of this zone. Also, Reticulofenestra pseudoumbilica is not recorded below 528-4,CC. In the lower part of this zone, Dictyococcites bisectus has its highest occurrence in Sample 528-6-1, 40-41 cm, and aff. Dictyococcites dictyodus has its highest occurrence in 528-6-2, 40-41 cm. Sphenolithus delphix has a very short stratigraphic range and is restricted to the lower part of Zone NN1. Sphenolithus capricornutus was not recorded in Hole 528.

The top of the Oligocene is placed in Sample 528-7-1, $10-12 \mathrm{~cm}$, where the highest occurrence of $S$. ciperoensis is recorded. The first downhole appearance of Chiasmolithus altus is found in 528-7-2, 30-32 cm, where rare Ericsonia fenestrata are observed. Perhaps because of the depth of the site, Helicosphaera recta and $H$. perch-nielseniae are not recovered in the upper Oligocene of Hole 528.

The preservation of calcareous nannofossils in Core 1 is moderate. In the Miocene and upper Oligocene inter$\mathrm{val}$, the state of preservation becomes moderate to poor. Dissolution and overgrowth are so extensive that small coccoliths are totally eliminated, and discoasters and other solution-resistant coccoliths are strongly overgrown.

\section{Hole 528A $\left(28^{\circ} 31.16 \prime\right.$ S; $02^{\circ} 18.97^{\prime} \mathrm{E}$; water depth: $3815 \mathrm{~m}$ )}

Hole 528A was drilled with hydraulic piston coring. Sediments were continuously cored from 0 to 130.5 me- 
Table 5. Nannofossil distribution at Hole 527, DSDP Leg 74.

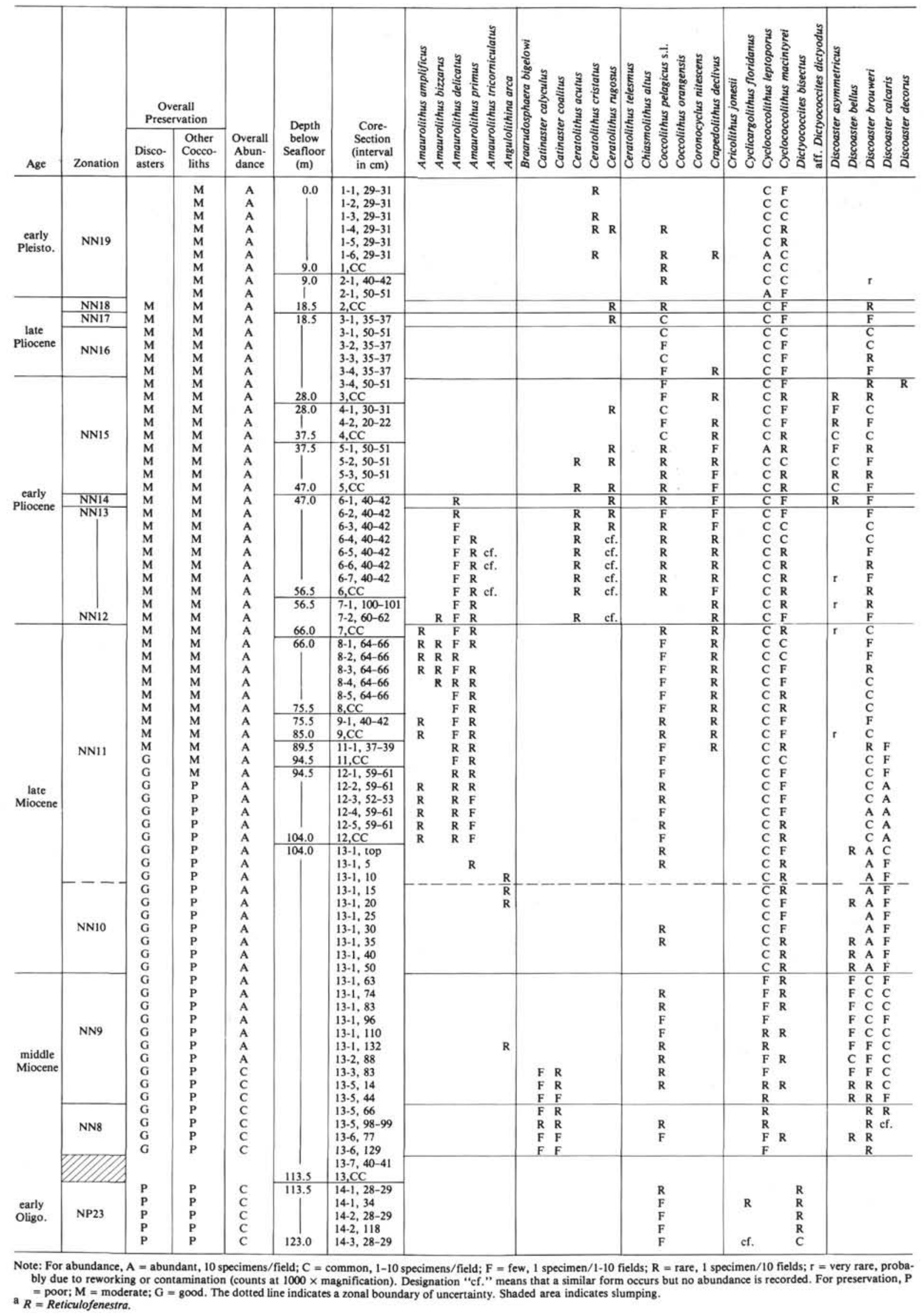


Table 5. (Continued).

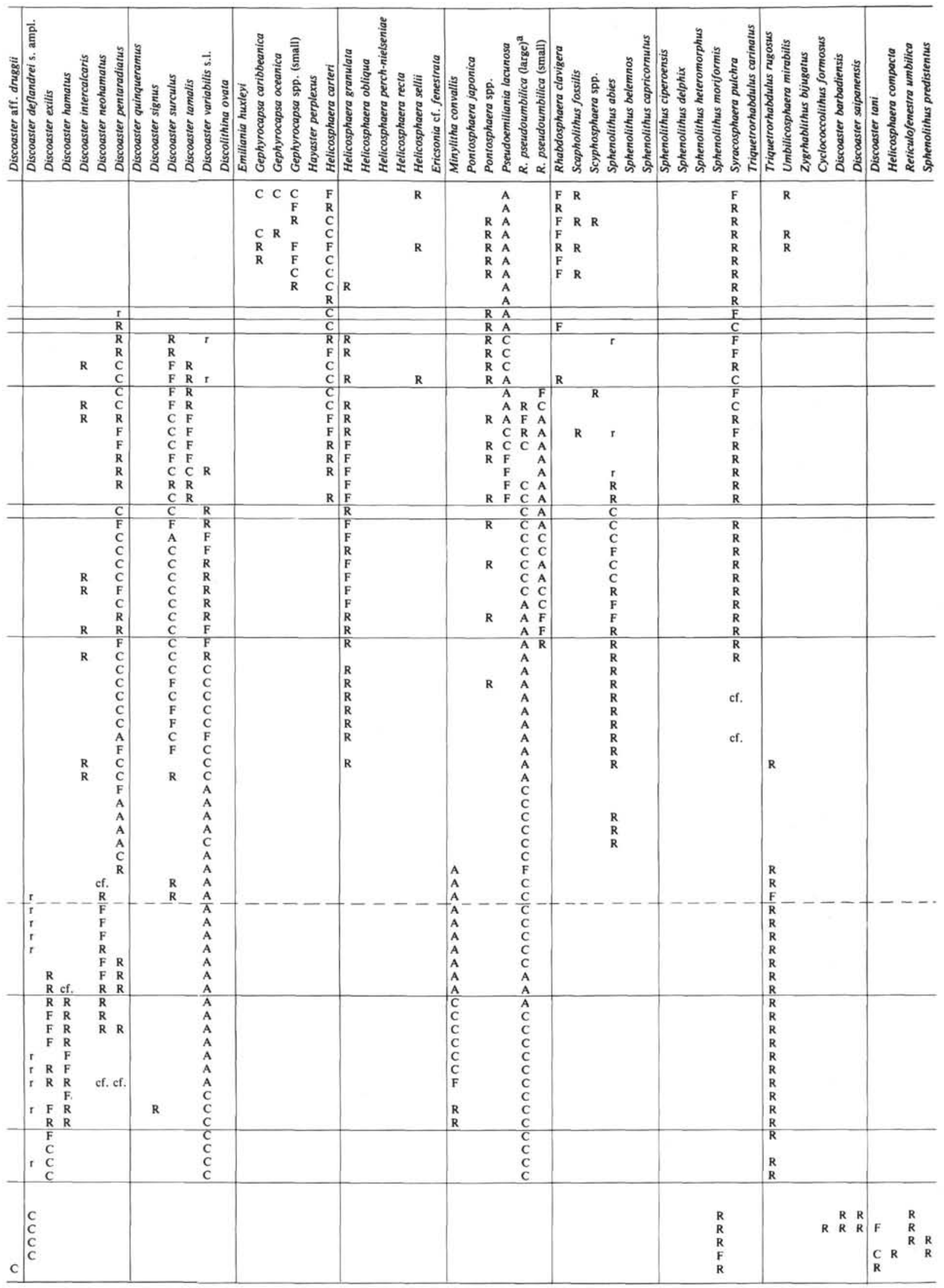


Table 6. Nannofossil distribution at Hole 528, DSDP Leg 74.

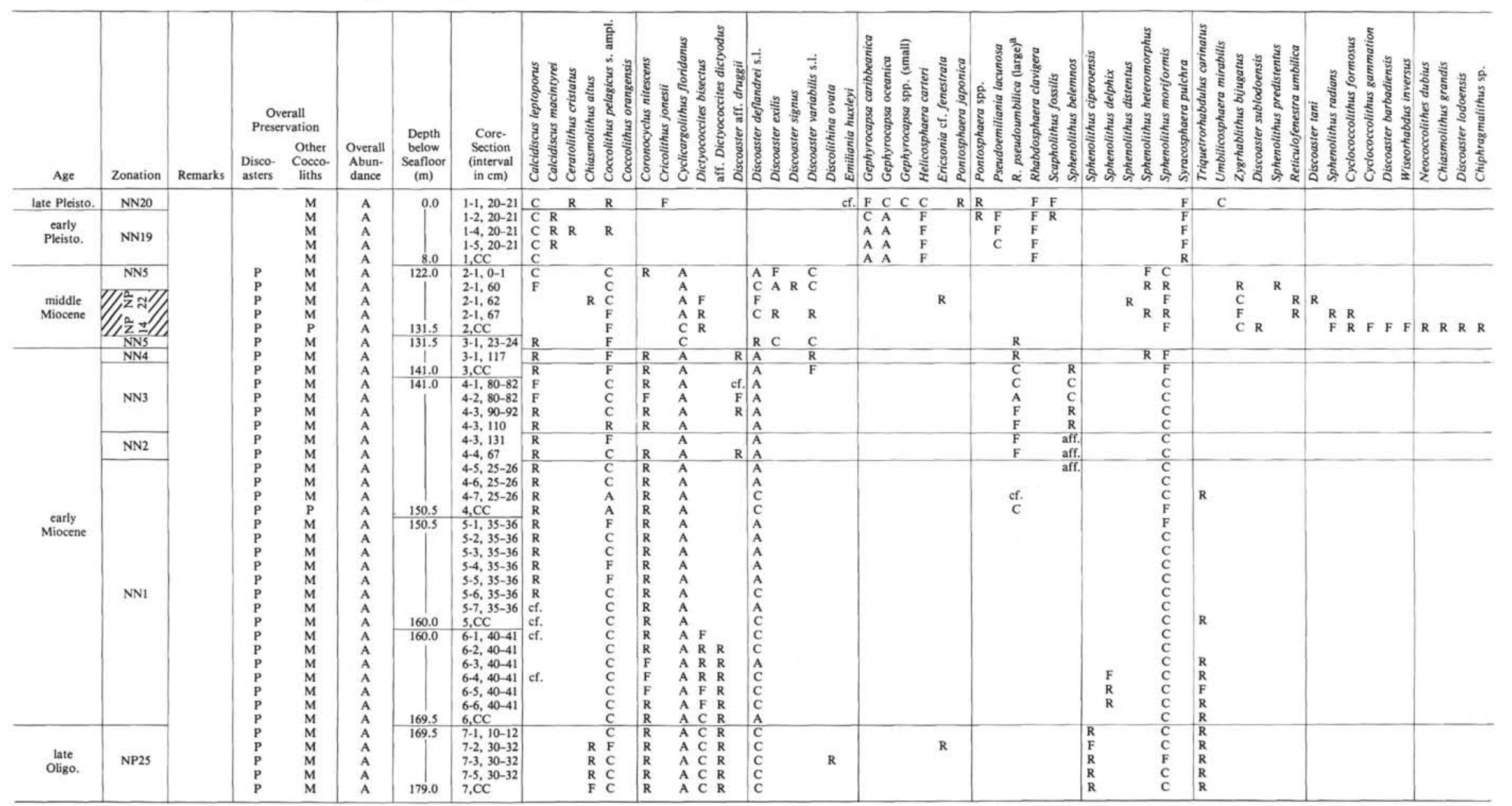

Note: For abundance, $A=$ abundant, 10 specimens/field; $C=$ common, $1-10$ specimens/field; $F=$ few, 1 specimen $/ 110$ fields; $R=$ rare, 1 specimen $/ 10$ fields; $r=$ very rare, probably due to reworking or contamination (counts at $1000 \times$ magnification). Species looked for but

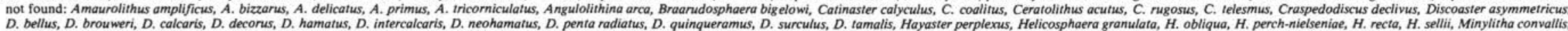
esignation "cf." means that a similar form occurs but no abundance is recorded. For preservation, $\mathrm{P}=$ poor; $\mathrm{M}=$ moderate; $\mathrm{G}=$ good. Shaded area indi$\mathrm{a}_{R,}$ cates slumping. 
ters sub-bottom to recover the interval of coring gap of Hole 528. A major hiatus was observed between Sample 528A-28, CC and Core 528A-29, top. The entire lower Miocene and the lower part of the middle Miocene are missing in this hole, which is not compatible with Hole 528. A checklist of the calcareous nannofossil distribution of the entire Hole 528A is given in Table 7.

Sample 528A-1-1, 28-29 cm is assigned to the late Pleistocene Zone NN20, based on the common occurrence of Gephyrocapsa oceanica and G. caribbeanica in the absence of Pseudoemiliania lacunosa. The presence of Emiliania huxleyi in this sample is not confirmed. Samples 528A-1-1, 120-122 cm through 528A-5-3, 19$20 \mathrm{~cm}$ belong to the early Pleistocene Zone NN19, based on the presence of $P$. lacunosa together with $G$. oceanica and G. caribbeanica. Calcidiscus macintyrei, a species no younger than 1.51 m.y. (Gartner, 1977), is present throughout this interval.

The interval between Samples 528A-5-4, 19-20 cm and $528 \mathrm{~A}-6-3,19-20 \mathrm{~cm}$ is assigned to the late Pliocene Zone NN18, based on the few to common occurrences of Discoaster brouweri. Gephyrocapsa oceanica and G. caribbeanica are not present in this zone. The rare occurrence of $D$. pentaradiatus in this interval is interpreted as redeposited because of their poor preservation. Helicosphaera granulata becomes common in this zonal interval of Hole 528A. The interval between Sections $528 \mathrm{~A}-6-3,111 \mathrm{~cm}$ and $528 \mathrm{~A}-7-2,100 \mathrm{~cm}$ belongs to the late Pliocene Zone NN16, based on the occurrence of $D$. surculus together with $D$. pentaradiatus and $D$. brouweri in this interval. Discoaster tamalis and D. asymmetricus have their highest occurrences in the lower part of the zone. Zone NN17 apparently is not developed in this hole. It is unclear whether this represents a minor hiatus, whether the sampling intervals are not close enough, or whether the marker species were excluded from this area.

The interval from Sample 528A-7-3, 40-41 cm to Section 528A-11-3, top, is assigned to the early Pliocene Zone NN15 because of the presence of Reticulofenestra pseudoumbilica in the absence of Amaurolithus delicatus. Both large and small $R$. pseudoumbilica are traced up to Sample 528A-7-3, 40-41 cm, whereas Sphenolithus abies has its highest occurrence in Sample 528A-10, $\mathrm{CC}$, in the lower part of Zone NN15. Pseudoemiliania lacunosa is present throughout this zonal interval. It is, however, atypically small in the lower part of this zone and is not recorded in the underlying zone.

The interval between Samples 528A-11, CC and 528A$13-2,63-64 \mathrm{~cm}$ is included in the early Pliocene Zone NN14, based on the co-occurrence of D. asymmetricus and $A$. delicatus. Discoaster tamalis has its lowest occurrence in this zone. The single Sample 528A-13-3, $63-64 \mathrm{~cm}$ is assigned to the early Pliocene Zone NN13, based on the presence of Ceratolithus rugosus in the absence of $D$. asymmetricus. In the same sample, rare $A$. tricorniculatus and the highest occurrence of $A$. bizzarus are recorded.

The interval between Section 528A-13-4, base, and Sample 528A-14-2, 51-52 cm represents the Pliocene/ Miocene Zone NN12 transition, based on the absence of the Pliocene Ceratolithus sp. and the typical Miocene $A$. amplificus. Discoaster variabilis first appears in the lower part of Zone NN15 and suddenly becomes important in the assemblage in this zone.

The Miocene top is tentatively placed in Sample 528A$14, \mathrm{CC}$, where the highest occurrence of typical $\mathrm{A}$. amplificus is recorded. Because of the depth of the site, $D$. quinqueramus, index species for the late Miocene Zone NN11, is extremely rare in the upper Miocene of this hole. The interval between 528A-14,CC and 528A-23,CC belongs to the upper part of the late Miocene Zone NN11 because of the consistent presence of Amaurolithus sp. and the absence of D. neohamatus. Discoaster surculus, $A$. bizzarus, and $H$. granulata (dissolution effect?) do not extend down to the lower part of this interval, whereas Triquetrorhabdulus rugosus first occurs sporadically in this interval. Small $R$. pseudoumbilica are still common to abundant in this entire interval. They are, however, no longer recorded below Core 23 .

The interval between Sample 528A-24-1, 70-71 cm and 528A-25,CC is included in the lower part of the late Miocene Zone NN11 or Zone NN10, based on the absence of Amaurolithus sp. and D. hamatus. Discoaster neohamatus and Minylitha convallis have their highest occurrences in Sample 528A-24-1, 70-71 cm. This entire interval is characterized by the common presence of $M$. convallis, $D$. variabilis, and $D$. brouweri with long slender rays, together with $D$. neohamatus. Discoaster bellus has it highest occurrence in 528A-25-3, 59-60 cm in this interval. Because of the scarcity of $D$. quinquera$m u s$, the NN11/NN10 boundary can not be identified with certainty in this hole.

The total range of $D$. hamatus, recorded from Section $528 \mathrm{~A}-26-1,50 \mathrm{~cm}$ to Sample $528 \mathrm{~A}-27-2,38-39 \mathrm{~cm}$, places this interval into the middle Miocene Zone NN9. Minylitha convallis remains very abundant in the upper part of this interval and disappears in the underlying Zone NN8. Discoaster pentaradiatus is missing below Sample 528A-26-1, $50 \mathrm{~cm}$. Discoaster neohamatus has its lowest occurrence and Catinaster calyculus has its highest occurrence in the same core, in Sample 528A-26$3,54-56 \mathrm{~cm}$. Discoaster bellus, on the other hand, has the same lowest occurrence as D. hamatus in Core 27 in Sample 528A-27-2, 38-39 cm.

Sample 528A-27-2, $150 \mathrm{~cm}$ to Sample 528A-27, CC is included in the middle Miocene Zone NN8, based on the occurrence of $C$. calyculus and $C$. coalitus in the absence of $D$. hamatus. Discoaster variabilis, $D$. exilis, and rare $D$. brouweri are the main discoaster components in this interval. Discoaster exilis is not observed above this zone in this hole. The interval between Sample 528A-28$1,58 \mathrm{~cm}$ and Sample 528A-28, CC is assigned to the middle Miocene Zone NN7, based on the absence of $C$. calyculus and $C$. coalitus. Other species components are almost identical to the overlying Zone NN8, except for the first downhole occurrence of $D$. deflandre $i$ in this interval. Typical D. kugleri, the index species for Zone NN7, is absent. Some specimens of Coronocyclus nitescens and Cyclicargolithus floridanus were found in Sample 528A-28,CC, which might indicate an age of the middle Miocene Zone NN6 or the fact of reworking from intervals of older age. 
Table 7. Nannofossil distribution at Hole 528A, DSDP Leg 74.

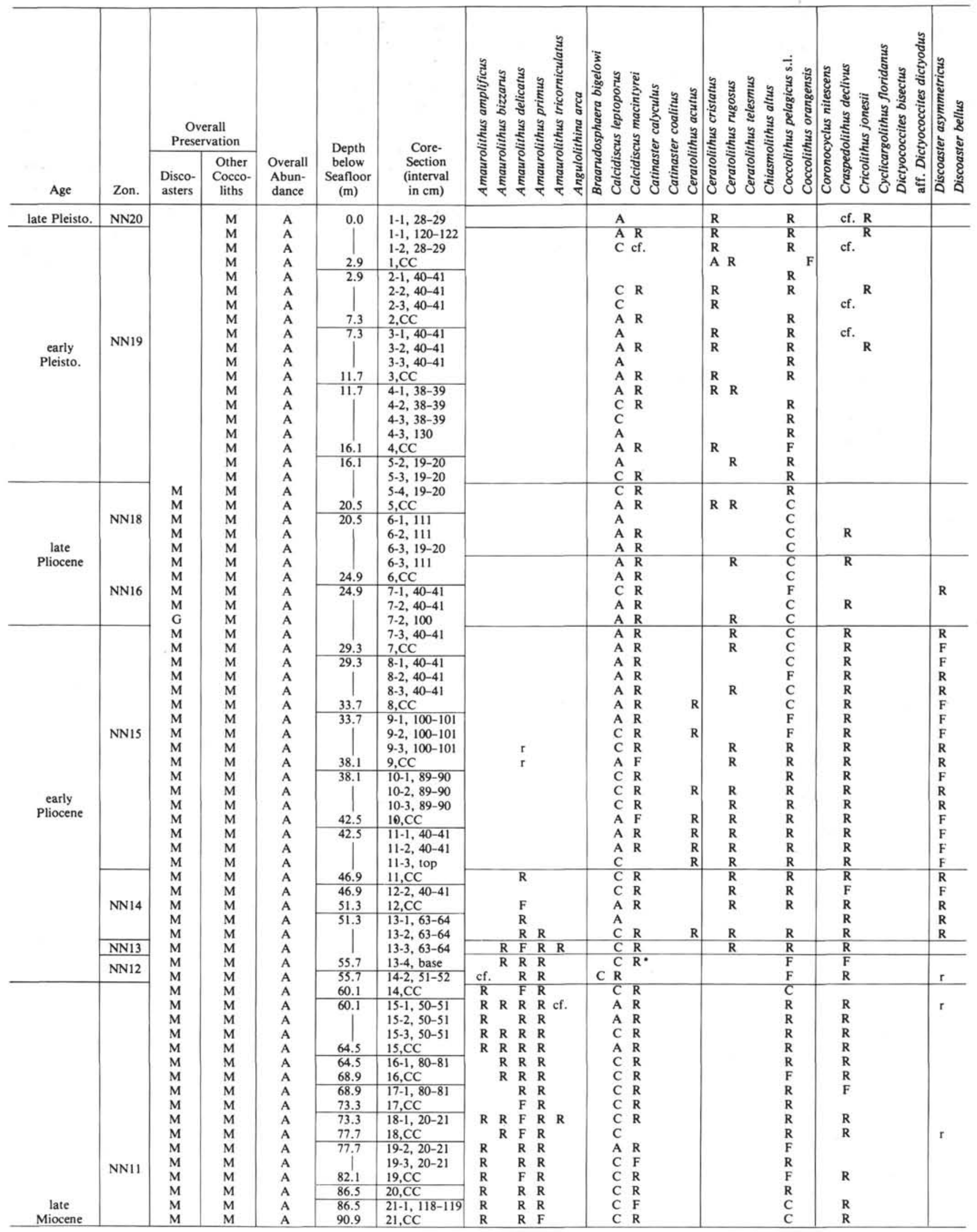




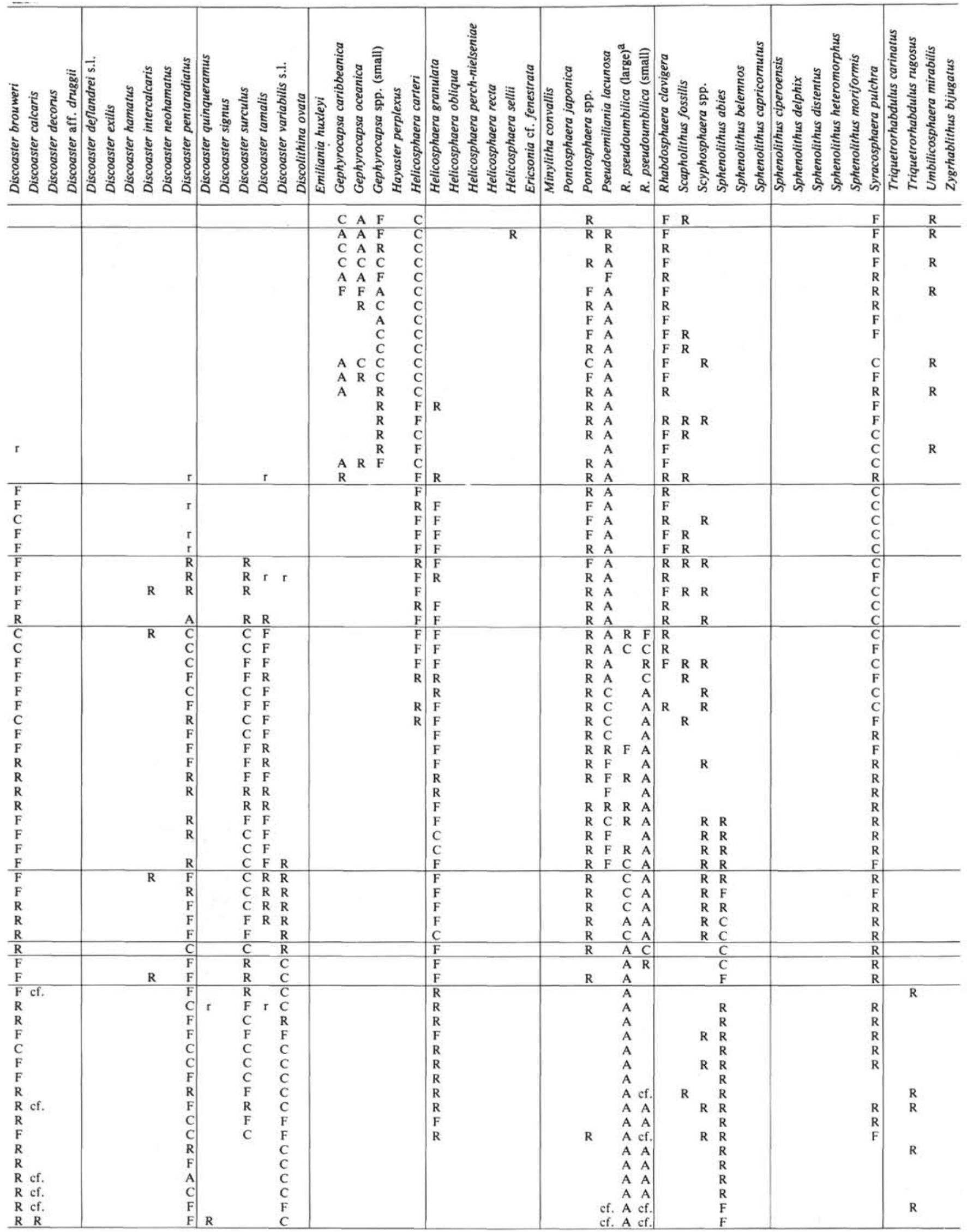


Table 7. (Continued).

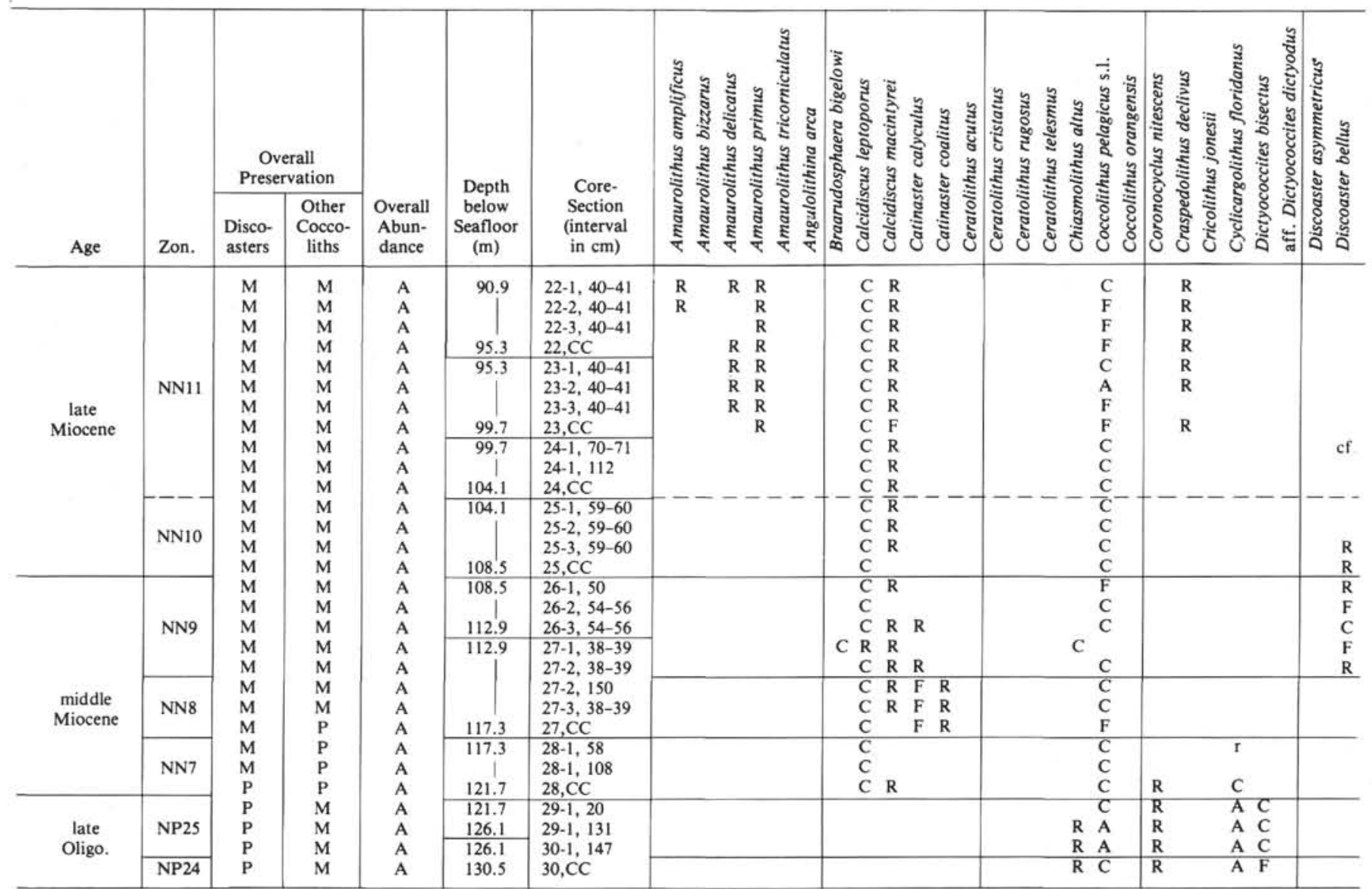

Note: For abundance, $\mathrm{A}=$ abundant, 10 specimens/field; $\mathrm{C}=$ common, $1-10$ specimens $/$ field; $\mathrm{F}=$ few, 1 specimen $/ 110$ fields; $\mathrm{R}=\mathrm{rare}, 1$ specimen $/ 10$ fields; $\mathrm{r}=$ very rare, probably due to reworking or contamination (counts at $1000 \times$ magnification). Designation "cf." means that a similar form occurs but no abundance is recorded. For preservation, $\mathbf{P}=$ poor $\mathbf{M}=$ moderate $\mathbf{G}=\mathrm{good}$. The dotted line indicates a zonal boundary of uncertainty.

${ }^{\text {a }} R=$ Reticulofenestra.

A sharp assemblage change occurs between Sample 528A-28, CC and Section 528A-29-1, $20 \mathrm{~cm}$. The interval between 528A-29-1, $20 \mathrm{~cm}$ and 528A-30-1, $147 \mathrm{~cm}$ is typical of the late Oligocene Zone NP25, based on the consistent presence of $S$. ciperoensis. Other components in the assemblage are Coccolithus pelagicus, Coronocyclus nitescens, Cyclicargolithus floridanus, Dictyococcites bisectus, Discoaster deflandrei, S. moriformis, Zygrahablithus bijugatus, and rare Chiasmolithus altus. Next, a few S. distentus, recorded in Sample 528A-30, $\mathrm{CC}$, place this sample in the late Oligocene Zone NP24. Obviously a major hiatus occurs in the interval between $528 \mathrm{~A}-28, \mathrm{CC}$ and $528 \mathrm{~A}-29-1,20 \mathrm{~cm}$. The entire early Miocene and part of the middle Miocene are missing. This result, however, is not comparable to the same depth interval in Hole 528. Another possibility is that the entire late Oligocene in Cores 29 and 30 is reworked material because of slumping, which occurs in the NN6-NN7 zonal interval of the middle Miocene. This problem cannot be resolved, because no further cores were taken in this hole.

The preservation of calcareous nannofossils recovered in Hole 528A ranges from moderate to poor. The Pleistocene to upper Miocene sediment in general yield moderately preserved nannofossils. Dissolution and re- crystallization of placoliths increase downhole, whereas discoasters in this interval show moderate overgrowth.

Below Sample 528A-23,CC, where the color of the sediments changes sharply, the state of preservation of nannofossils also deteriorates significantly. Most species are strongly etched or fragmented. Small specimens are totally eliminated. By contrast, the discoasters remain unaffected or show a slight increase in number. Preservation improves in Core 28, where large placoliths and discoasters show moderate overgrowth.

The nannofossils from the upper Oligocene of this hole show moderate to poor preservation. Both discoasters and coccoliths show strong overgrowth.

Hole $529\left(28^{\circ} 55.83^{\prime} \mathrm{S}, 02^{\circ} 46.08\right.$ ' E; water depth: $\mathbf{3 0 3 5} \mathbf{~ m}$ )

Only one hole was drilled at Site 529. Hole 529 was drilled with conventional rotary coring. Though this hole is located between Sites 525 and 528, the sedimentary sequence recovered in the Neogene and Quaternary does not show a transition between the two. A hiatus occurs between Cores 4 and 5, where the lower Pliocene is underlain by the middle Miocene. Three apparent slump deposits were observed in the Neogene and Quaternary interval: one occurs in the early Pleistocene (NN19), one 
Table 7. (Continued).

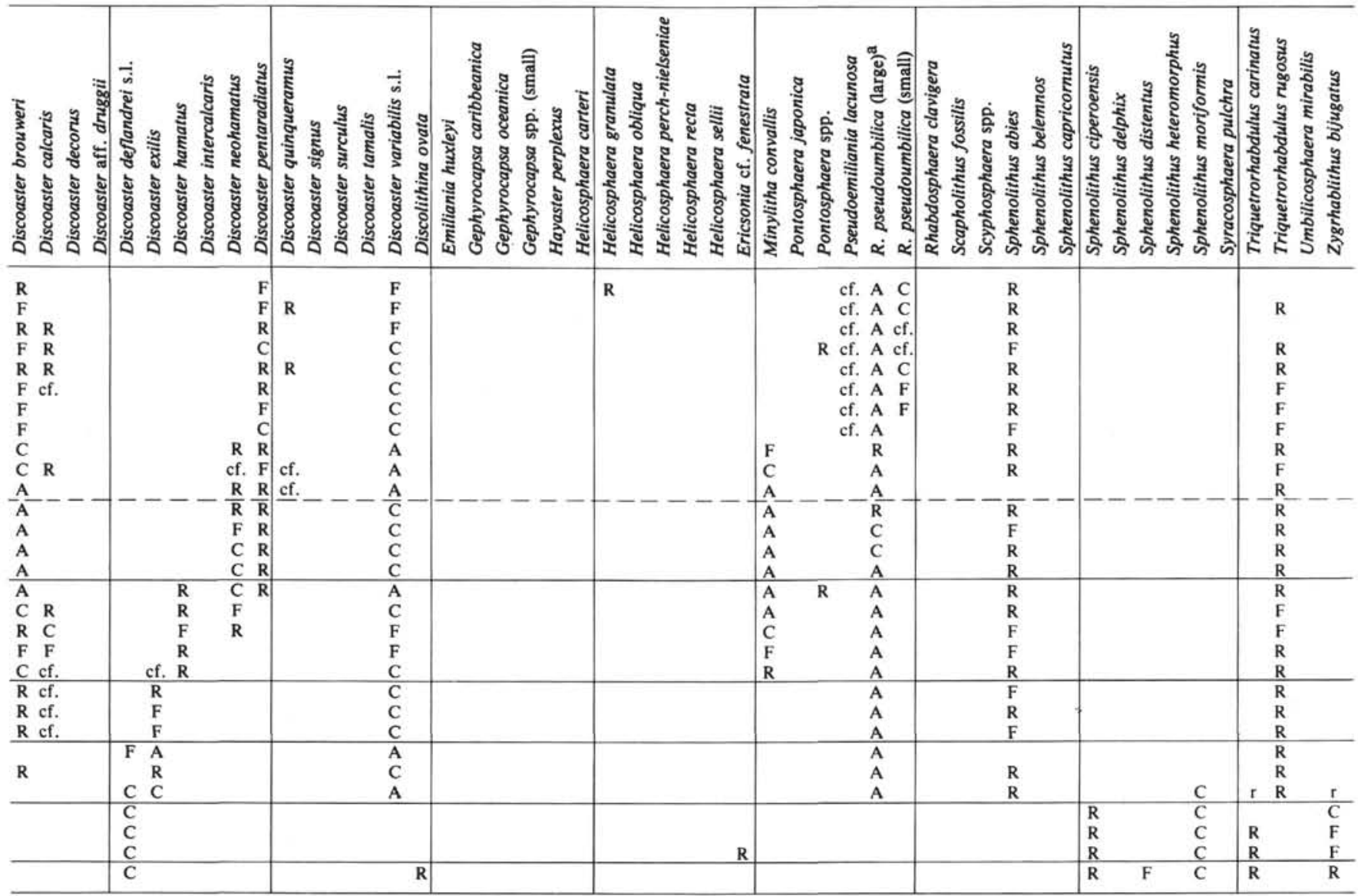

in the upper part of the early Miocene, and one in the basal Miocene. Table 8 represents the Neogene and Quaternary calcareous nannofossil distribution of Hole 529 .

Section 529-1-1, top, through Sample 529-1-1, 40-41 $\mathrm{cm}$ contains abundant Emiliania huxleyi, with some Gephyrocapsa oceanica, and belongs to the latest Pleistocene Zone NN21. Section 529-1-1, $150 \mathrm{~cm}$ contains abundant Gephyrocapsa caribbeanica and G. oceanica, without Pseudoemiliania lacunosa and E. huxleyi, and belongs to the late Pleistocene Zone NN20. The top of the early Pliocene Zone NN19 is located in Sample 529$1-2,40-41 \mathrm{~cm}$, where the highest occurrence of $P$. lacunosa is recorded. Zone NN19 extends down to Sample 529-2-6, 40-41 cm. Within Zone NN19, the subinterval between Sections 529-1-2, $73 \mathrm{~cm}$ and 529-2-2, 150 $\mathrm{cm}$, however, consists of redeposited sediment. The nannofossil assemblages recovered from this interval are middle Pliocene (NN14-NN16).

The upper Pliocene is very thin in Hole 529. Zone NN18 is recorded only in Sample 529-2,CC, where the highest occurrence of Discoaster brouweri is found. Gephyrocapsa oceanica and $G$. caribbeanica are not found in Core 2. The next sample, 529-3-1, 30-31 cm, belongs to the late Pliocene Zone NN16, based on the occurrence of $D$. surculus with $D$. pentaradiatus and $D$. asymmetricus. Zone NN17 is apparently missing. It is uncertain whether this zone is cut out by a minor hiatus or whether it is contained in the interval within adjacent samples.

The interval between Samples 529-3-1, 30-31 cm and 529-4-6, 40-41 cm is included in the early Pliocene Zone NN15, based on the abundance of Reticulofenestra pseudoumbilica (both large and small forms). Pseudoemiliania lacunosa is still quite common in this interval. Discoasters recorded in this zone are $D$. brouweri, $D$. pentaradiatus, $D$. surculus, $D$. tamalis, $D$. asymmetricus, $D$. variabilis, and $D$. intercalcaris. The next sample, 529-4,CC, belongs to the early Pliocene Zone NN14, based on the presence of Amaurolithus delicatus. Sphenolithus abies has its highest occurrence in this sample, too. At other sites of DSDP Leg $74 \mathrm{~S}$. abies extends upward to the lower part of zone NN15, and therefore a minor hiatus (or a sampling gap?) is inferred between Samples 529-4-6, $40-41 \mathrm{~cm}$ and $529-4, \mathrm{CC}$.

Core 5 has very poor recovery. Samples from Section 1 and the core catcher contain Catinaster calyculus and $C$. coalitus and belong to the middle Miocene Zone NN8. Other important species included in the assemblage are Coccolithus pelagicus, Craspedolithus declivus $(?=$ Cyclococcolithus rotula), Calcidiscus leptoporus, D. brouweri (the uppermost sample only), D. variabilis, Helicosphaera granulata, $R$. pseudoumbilica (large form only), S. abies, and Triquetrorhabdulus rugosus. Obviously, a major hiatus occurs between Core 4 and the top 
Table 8. Nannofossil distribution at Hole 529, DSDP Leg 74.

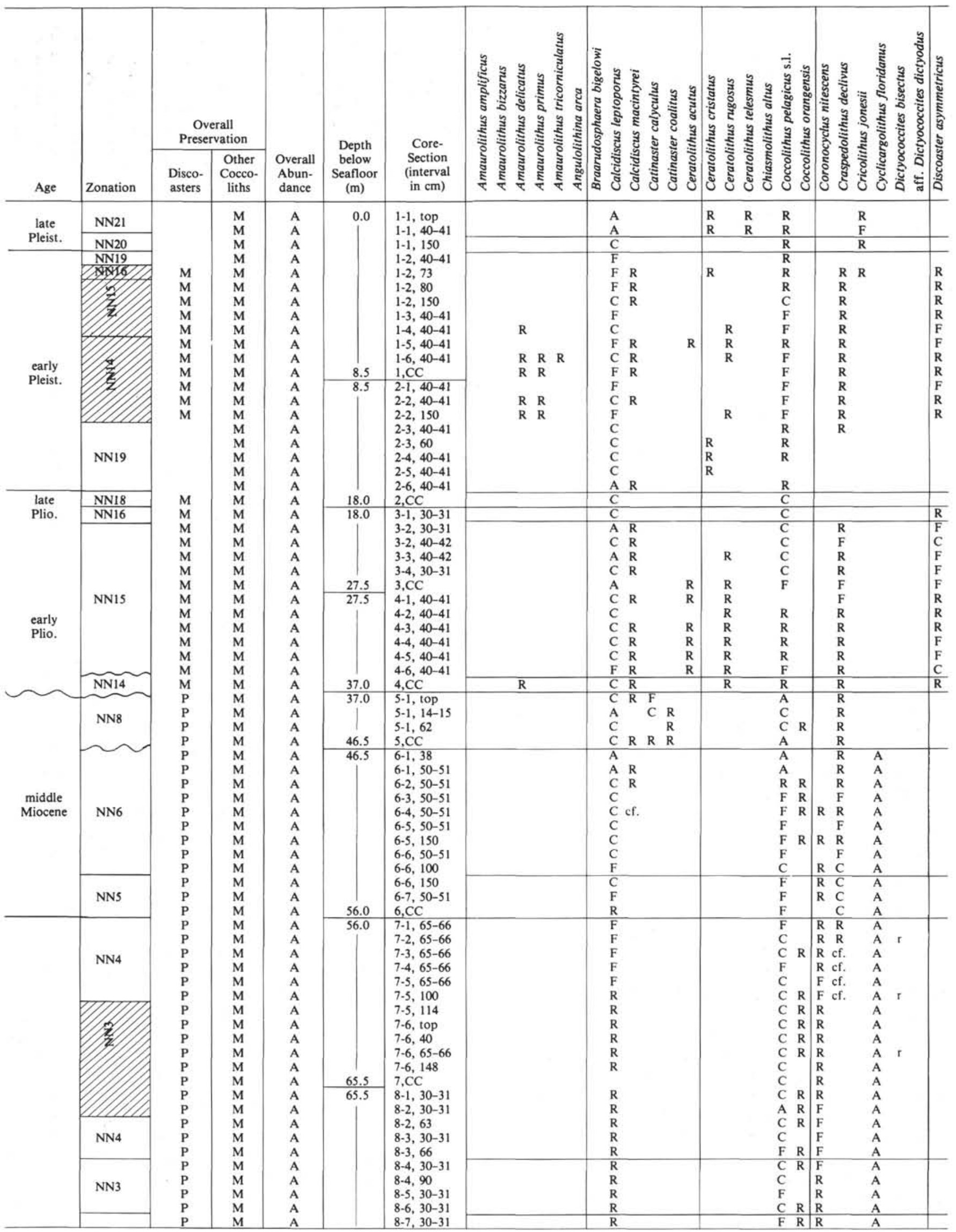


Table 8. (Continued).

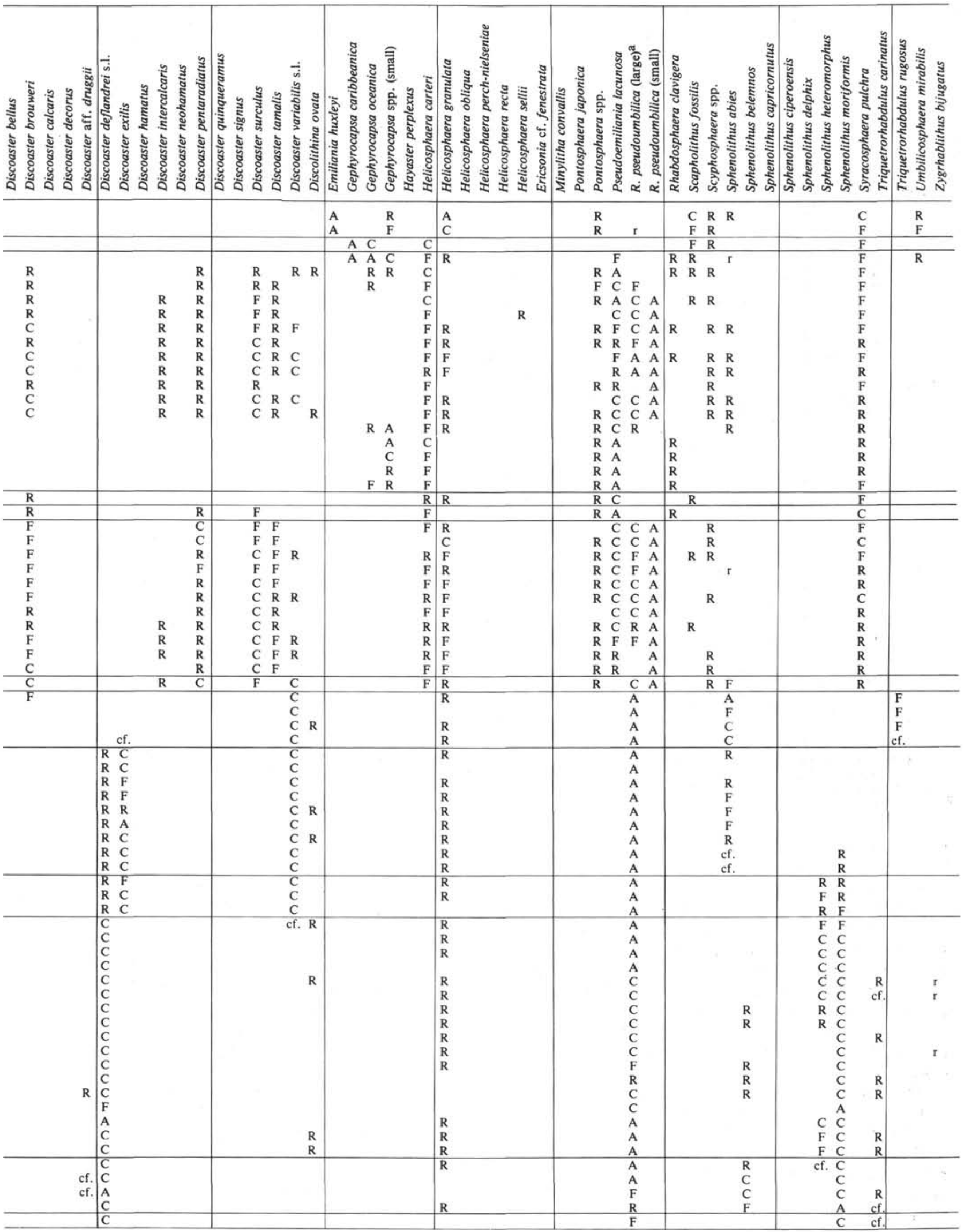


Table 8. (Continued).

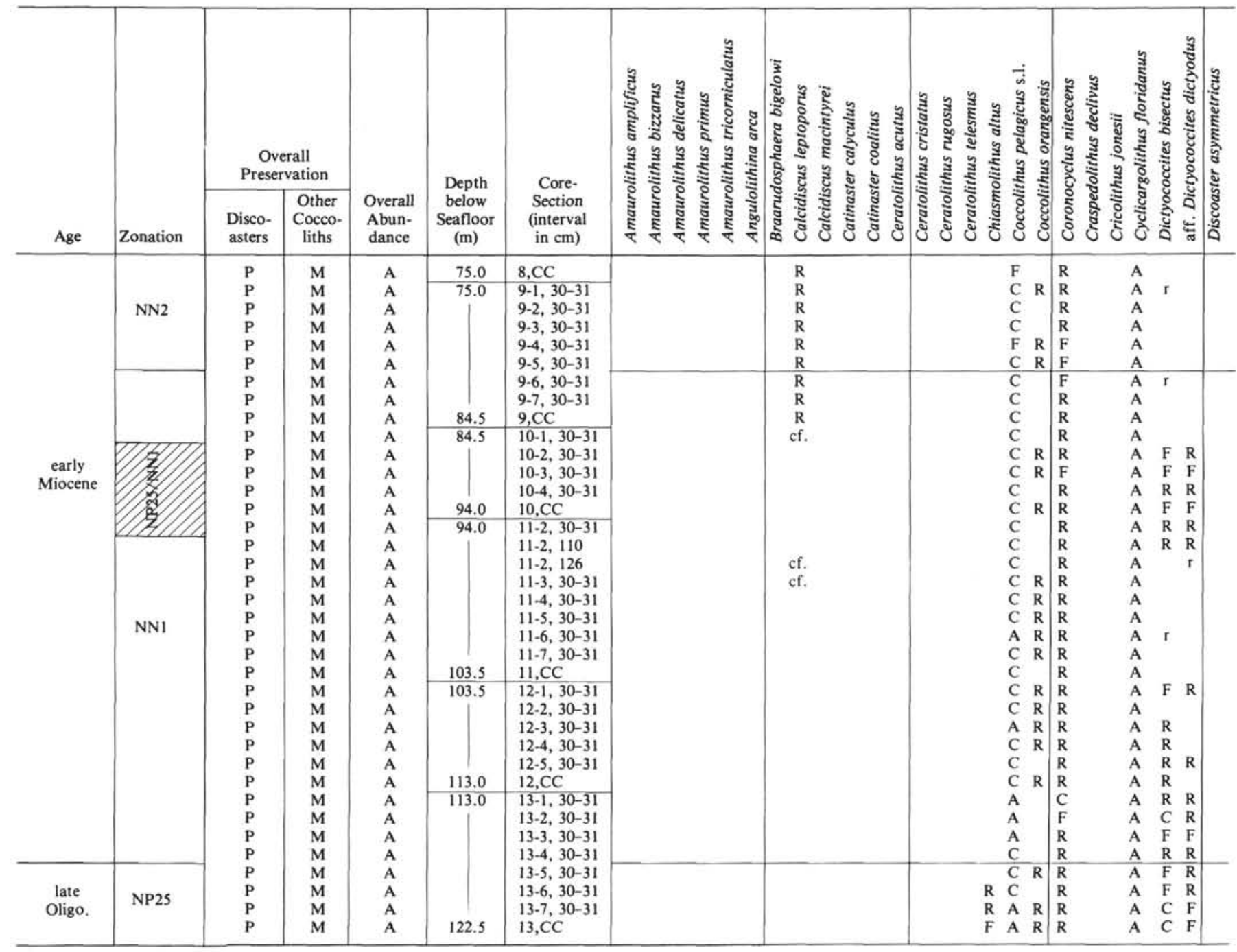

Note: For abundance, $A=$ abundant, 10 specimens $/$ field; $C=$ common, $1-10$ specimens $/$ field $; \mathrm{F}=$ few, 1 specimen $/ 1-10$ fields; $R=$ rare, 1 specimen $/ 10$ fields; $r=$ very rare, probably due to reworking or contamination (counts at $1000 \times$ magnification). Designations "cf." and "aff." mean that a similar form occurs but no abundance is recorded. For preservation, $\mathrm{P}=$ poor; $\mathrm{M}=$ moderate; $\mathrm{G}=$ good. Shaded areas indicate slumping.

${ }^{a}=$ Reticulofenestra.

of Core 5. The sediment representing the interval from Zone NN9 through most the NN14 is missing.

Another significant assemblage change occurs in Core 6. Sections 529-6-1, $38 \mathrm{~cm}$ through 529-6-6, $100 \mathrm{~cm}$ are assigned to the middle Miocene Zone NN6, based on the abundant occurrence of Cyclicargolithus floridanus. Also, Coronocyclus nitescens, $D$. deflandrei, and $D$. exilis have their first downhole occurrence in this zonal interval. Calcidiscus macintyrei, on the other hand, does not occur below this zone. Zone NN7 is not observed in Hole 529, probably because of the poor recovery for Core 5 .

The highest occurrence of $S$. heteromorphus is traced up to Section $529-6-6,150 \mathrm{~cm}$. The interval between $\mathrm{Sec}-$ tion 529-6-6, $150 \mathrm{~cm}$ and Sample 529-6,CC is included in the middle Miocene Zone NN5, based on the occurrence of $S$. heteromorphus with common $D$. exilis and $D$. variabilis. Though $D$. deflandrei is present in this interval, it is quantitatively insignificant.
The interval between Samples 529-7-1, 65-66 cm and $529-8-3,66 \mathrm{~cm}$ is attributed to the early Miocene Zone NN4, based on the co-occurrence of S. heteromorphus with common $D$. deflandrei. Discoaster exilis and $D$. variabilis are no longer present in this interval. Within the NN4 zone, the short interval between Section 529$7-5,114 \mathrm{~cm}$ and Sample 529-8-2, 30-31 cm consists of redeposited sediments. The nannofossil assemblage recorded from this subinterval indicates early Miocene Zone NN3, based on the occurrence of $S$. belemnos in the absence of $S$. heteromorphus. (The possibility that this inferred redeposited sequence was induced by coring cannot be precluded, because the site was cored by rotary drilling rather than hydraulic piston coring.)

The interval between Samples 529-8-4, 30-31 cm and $529-8-6,30-31 \mathrm{~cm}$ is assigned to the early Miocene Zone NN3, based on the total range of $S$. belemnos. The interval between Samples 529-8-7, 30-31 cm and 529-9-5, $30-31 \mathrm{~cm}$ is the early Miocene Zone NN2, based on the 
Table 8. (Continued).

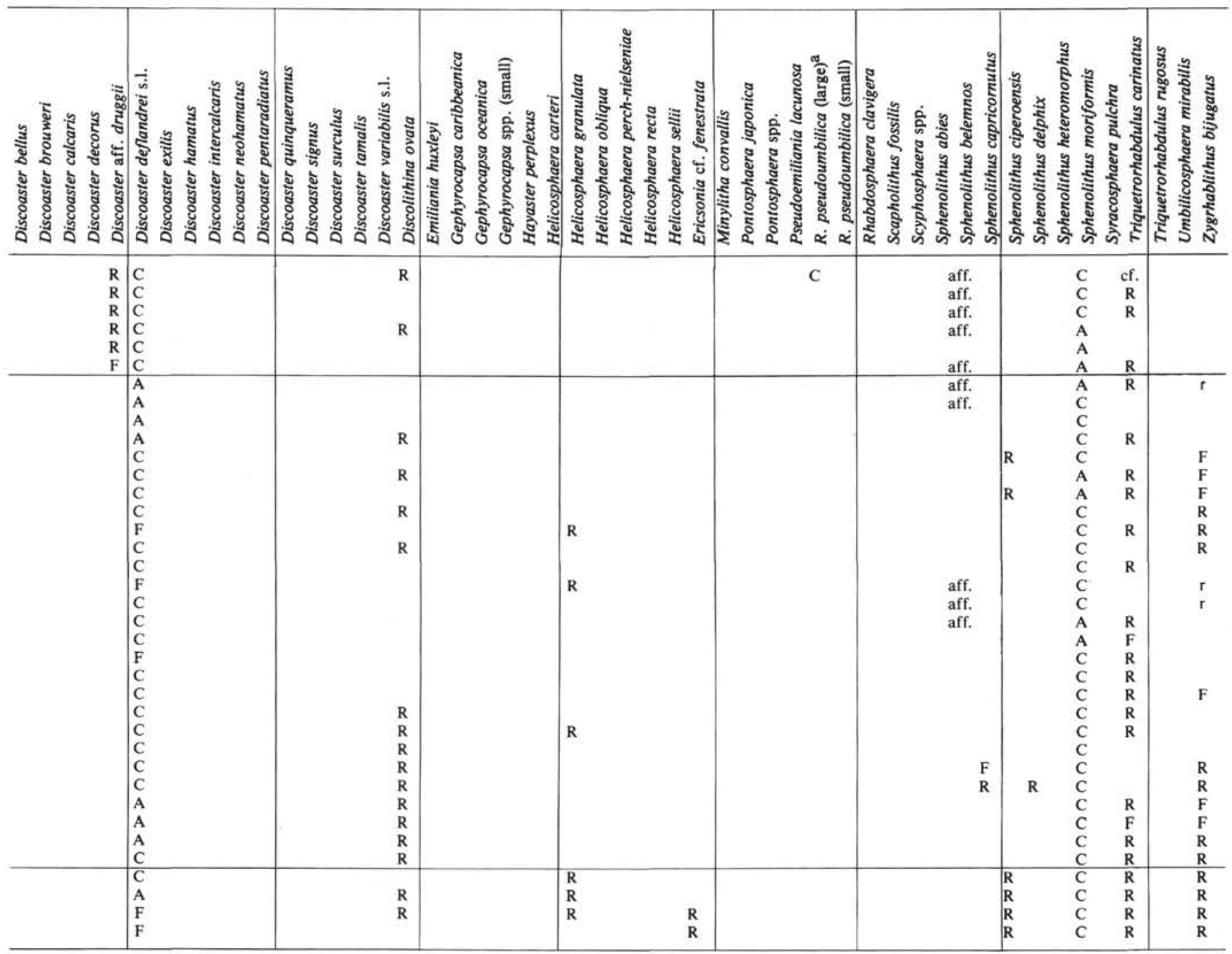

absence of $S$. belemnos and the presence of Discoaster sp. aff. D. druggii. Sphenolithus sp. aff. S. belemnos $(?=S$. dissimilis $)$, however, still occurs sporadically. $R e$ ticulofenestra pseudoumbilica, on the other hand, is no longer recorded below the upper part of this zonal interval in this hole.

The long interval between Samples 529-11-2, 30-31 $\mathrm{cm}$ and $529-13-4,30-31 \mathrm{~cm}$ is included in the early Miocene zone NN1, based on the absence of Discoaster sp. aff. D. druggii and S. ciperoensis. Calcidiscus leptopor$u s$ is not recorded below the upper part of this interval. In the lower part of this interval, Dictyococcites bisectus aff. D. dictyodus and Zygrahablithus bijugatus have their highest occurrences in Sample 529-12-1, 30-31 cm. Sphenolithus delphix and $S$. capricornutus have very short ranges and are restricted to the lower part of Zone NN1 in Hole 529. In the upper part of the NN1 zonal interval, Dictyococcites bisectus, $D$. dictyodus, and Z. bijugatus, together with rare $S$. ciperoensis, consistently occur between Sample 529-10-2, 30-31 cm and Section 529-11-2, $110 \mathrm{~cm}$. Such a nannofossil distribution suggests that this short sub-interval is represented by rede- posited sediments from the latest Oligocene/earliest Miocene boundary.

The top of the Oligocene is placed in Sample 529-13$5,30-31 \mathrm{~cm}$, where the highest occurrence of $S$. ciperoensis is recorded. A little downward, the highest occurrence of Chiasmolithus altus is found in Sample 529-13$6,30-31 \mathrm{~cm}$, whereas the highest occurrence of Ericsonia fenestrata is located in 529-13-7, 30-31 cm. Probably because of the depth of site, neither Helicosphaera recta nor $H$. perch-nielseniae are recovered in the late Oligocene of Hole 529.

The preservation of the calcareous nannofossils recovered in Hole 529 is generally moderate. Dissolution and recrystallization of placoliths increase downhole. Discoasters are moderately preserved in the Pliocene. However, they show overgrowth in the entire Miocene, so that their recognizable diversity is very low within that interval.

\section{REMARKS ON SELECTED CALCAREOUS NANNOFOSSIL TAXA}

Most of the calcareous nannofossil species present in this study are well documented elsewhere and need no discussion. The state of pre- 
servation of the calcareous nannofossils is only moderate, which dictates a broader species concept during identification. This is especially true for the early to middle Miocene (NN1-NN9) discoasters. Overgrowth rather than dissolution has strongly affected the primary characters of this group of fossils, which has made precise identification at the species level uncertain.

Amaurolithus amplificus (Bukry) Gartner and Bukry, 1975

Amaurolithus bizzarus (Bukry) Gartner and Bukry, 1975

Amaurolithus delicatus Gartner and Bukry, 1975

Amaurolithus primus (Bukry and Percival) Gartner and Bukry, 1975

Amaurolithus tricorniculatus (Gartner) Gartner and Bukry, 1975

Angulolithina arca Bukry, 1973

Braarudosphaera bigelowi (Gran and Braarud) Deflandre, 1947

Catinaster calyculus Martini and Bramlette, 1963

Catinaster coalitus Martini and Bramlette, 1963

Ceratolithus acutus Gartner and Bukry, 1974

Ceratolithus cristatus Kamptner, 1954

Ceratolithus rugosus Bukry and Bramlette, 1968 includes Ceratolithus separatus Bukry, 1979

Ceratolithus telesmus Norris, 1965

Chiasmolithus altus Bukry and Percival, 1971

Coccolithus pelagicus (Wallich) Schiller, 1930 s. ampl.

Remarks. Coccolithus miopelagicus Bukry, 1971, is included with C. pelagicus s. ampl. Coccolithus miopelagicus is, however, much larger and is restricted to the middle and early Miocene.

Coronocyclus nitescens (Kamptner) Bramlette and Wilcoxon, 1967 includes Coronocyclus serratus Hay, Mohler and Wade, 1966

Coccolithus(?) orangensis Bukry, 1971

Cricolithus jonesii Cohen, 1965

Craspedolithus declivus (Kamptner) Nishida, 1970

Remarks. Cyclococcolithus rotula Kamptner, 1956, could be included with the same taxon.

Cyclicargolithus floridanus (Roth and Hay) Bukry, 1971

Calcidiscus leptoporus (Murray and Blackman) Kamptner, 1954

Remarks. Coccolithus radiatus Kamptner, 1955 might be included in this taxon. Typical Calcidiscus leptoporus first occurs in the NN2-NN3 zonal interval of DSDP Leg 74. Many circular forms which look like small $C$. leptoporus, however, occur in the Oligocene/Miocene boundary interval. Some other forms which are elliptical and occur in the Oligocene/Miocene boundary interval could be reworked Striatococcolithus pacificanus Bukry, 1971, though superficially they look like C. leptoporus in the light microscope.

Calcidiscus macintyrei Bukry and Bramlette, 1969

Dictyococcites bisectus (Hay, Mohler, and Wade) Bukry and Percival, 1971.

Remarks. Dictyococcites abisectus (Müller) Bukry and Percival, 1971 , with a central opening, is considered as a later form of $D$. bisectus and is included with that same taxon here.

aff. Dictyococcites dictyodus (Deflandre and Fert) Martini, 1969 is the same as Reticulofenestra lockeri Müller, 1970

Discoaster asymmetricus Gartner, 1969

Discoaster bellus Bukry and Percival, 1971

Discoaster brouweri Tan, 1927

Remarks. Discoaster triradiatus Tan, 1927, D. blackstockae Bukry, 1973, D. neorectus Bukry, 1971, D. brouweri rutellus Gartner, 1967 , and D. braarudii Bukry, 1973, are included with D. brouweri because, owing to poor preservation or to general scarcity, these similar species cannot be consistently identified or used for biostratigraphy.

Discoaster calcaris Gartner, 1967

Discoaster decorus Bukry, 1971

Discoaster deflandrei Bramlette and Riedel, 1954, s. ampl.

Remarks. Because of heavy overgrowth of the discoasters in the middle and lower Miocene, identification of a number of species is impractical. Forms common in the lower Miocene (and less common in middle Miocene) which may be included in Discoaster deflandrei s. ampl. are

Discoaster adamanteus Bramlette and Wilcoxon, 1967

Discoaster calculosus Bukry, 1971

Discoaster druggii Bramlette and Wilcoxon, 1967

Discoaster nephados Hay, 1967

Discoaster saundersii Hay, 1967

Discoaster trinidadensis Hay, 1967
Discoaster sp. aff. D. druggii Bramlette and Wilcoxon, 1967

Discoaster exilis Martini and Bramlette, 1963

Discoaster hamatus Martini and Bramlette, 1963

Discoaster intercalcaris Bukry, 1971

Discoaster neohamatus Bukry and Bramlette, 1969

Discoaster pentaradiatus Tan, 1927

Remarks. This taxon may include its earlier form Discoaster prepentaradiatus Bukry and Percival, 1971

Discoaster quinqueramus Gartner, 1969

Remarks. Discoaster berggrenii Bukry, 1971, is included with $D$. quinqueramus in this study.

Discoaster signus Bukry, 1971

Discoaster surculus Martini and Bramlette, 1963

Remarks. This taxon includes Discoaster icarus Stradner, 1972, or $D$. pseudovariabilis Bukry and Worsley, 1971 . Typical D. surculus is most common in the Pliocene, whereas D. icarus and $D$. pseudovariabilis are typically present in the upper Miocene interval.

Discoaster tamalis Kamptner, 1967

Discoaster variabilis Martini and Bramlette, 1963, s. ampl.

Remarks. This taxon includes

Discoaster aulakos Gartner, 1967

Discoaster bollii Martini and Bramlette, 1963

Discoaster challengeri Bramlette and Riedel, 1954

Discoaster divaricatus Hay, 1967

Discoaster kugleri Martini and Bramlette, 1963

Discoaster loeblichii Bukry, 1971

Discoaster moorei Bukry, 1971

Discoaster pansus (Bukry and Percival) Bukry, 1973

Discolithina ovata Levin and Joerger, 1967

includes Discolithina segmentata Bukry and Percival, 1971

Emiliania huxleyi (Lohmann) Hay and Mohler, 1967

Gephyrocapsa caribbeanica Boudreaux and Hay, 1967

Gephyrocapsa oceanica Kamptner, 1943

Remarks. This taxon may include Gephyrocapsa lumina Bukry, 1973 and $G$. omega Bukry, 1973. These two forms are, however, very rare in the samples studied.

Gephyrocapsa spp. (small)

Remarks. Gephyrocapsa aperta Kamptner, 1963, could be the dominant form of this group.

Hayaster perplexus (Bramlette and Riedel) Bukry, 1973

Helicosphaera carteri (Wallich) Kamptner, 1954

includes Helicopontosphaera kamptneri Hay and Mohler, 1967

Remarks. This taxon includes Helicosphaera wallichi (Lohmann) Okada and McIntyre, 1977, of the Quaternary.

Helicosphaera granulata (Bukry and Percival) Jafar and Martini, 1975

Remarks. Because of dissolution and recrystallization, Helicosphaera carteri can appear like $H$. granulata and may be identified as this taxon. This is especially the case in the Miocene interval. For this same reason $H$. intermedia Martini, 1965, and H. euphratis (Haq) Jafar and Martini, 1975, are included with H. granulata.

Helicosphaera obliqua Bramlette and Wilcoxon, 1967

Helicosphaera perch-nielseniae (Haq) Jafar and Martini, 1975

Helicosphaera recta (Haq) Jafar and Martini, 1975

Helicosphaera recta (Haq) Jafar and Martini, 1975

Helicosphaera sellii (Bukry and Bramlette) Jafar and Martini, 1975

Minylitha convallis Bukry, 1973

Pontosphaera japonica (Takayama) Nishida, 1971

Pontosphaera spp.

Pseudoemiliania lacunosa (Kamptner) Gartner, 1969

Reticulofenestra pseudoumbilica (Gartner) Gartner, 1969

Rhabdosphera calvigera Murray and Blackman, 1898

includes Rhabdosphaera stylifera Lomann, 1902

Scapholithus fossilis Deflandre, 1954

Scyphosphaera spp.

Remarks. Various forms of Scyphosphaera were found during this study. They are especially common in the lower Pliocene and the uppermost Miocene intervals of Site 525. Species of this genus are not resistant to dissolution; therefore they are very rare or even missing in the same interval of other sites (deeper sites). Detailed taxonomic work of this genus is not attempted in this study. Members of this group are documented as Scyphosphaera spp. 
Sphenolithus abies Deflandre, 1954

Remarks. Sphenolithus neoabies Bukry and Bramlette, 1969, is included with $S$. abies.

Sphenolithus belemnos Bramlette and Wilcoxon, 1967

Remarks. Species documented as aff. Sphenolithus belemnos in the tables could be $S$. dissimilis Bukry and Percival, 1971.

Sphenolithus capricornutus Bukry and Percival, 1971

Sphenolithus ciperoensis Bramlette and Wilcoxon, 1967

Sphenolithus heteromorphus Deflandre, 1953

Sphenolithus moriformis (Brönnimann and Stradner) Bramlette and

Wilcoxon, 1967

Remarks. Sphenolithus conicus Bukry, 1971, is included in the same taxon. Differentiation between $S$. abies and $S$. moriformis is in fact very difficult in the middle Miocene interval.

Sphenolithus distentus (Martini) Bramlette and Wilcoxon, 1967

Sphenolithus delphix Bukry, 1973

Syracosphaera pulchra Lohmann, 1902

Thoracosphaera spp.

Remarks. Species of this genus occur sporadically throughout the Neogene and Quaternary. They are more common in younger sediments. Detailed taxonomic study of this group is not attempted in this study.

Triquetrorhabdulus carinatus Martini, 1965

Triquetrorhabdulus milowii Bukry, 1971

Remarks. This species seems to occur in the lower Miocene of the studied area. Strong overgrowth, however, makes identification of this species difficult.

Triquetrorhabdulus rugosus Bramlette and Wilcoxon, 1967

Umbilicosphaera mirabilis Lohmann, 1902

Zygrahablithus bijugatus (Deflandre) Deflandre, 1959

Various reworked species were found also in some intervals. They are

Chiasmolithus grandis (Bramlette and Riedel) Radomski, 1968

Chiphragmalithus $\mathrm{sp}$.

Cyclococcolithus formosus Kamptner, 1963

Cyclococcolithus gammation (Bramlette and Sullivan) Sullivan, 1964
Discoaster barbadiensis Tan, 1927

Discoaster lodoensis Bramlette and Riedel, 1954

Discoaster sublodoensis Bramlette and Sullivan, 1961

Discoaster tanii Bramlette and Riedel, 1954

Ericsonia sp. cf. E. fenestrata (Deflandre and Fert) Stradner, 1968

Neococcolithes dubius (Deflandre and Fert) Black, 1967

Reticulofenestra umbilica (Levin) Martini and Ritzkowski, 1968

Sphenolithus distentus (Martini) Bramlette and Wilcoxon, 1967

Sphenolithus predistentus Bramlette and Wilcoxon, 1967

Sphenolithus radians Deflandre, 1952

Wiseorhabdus inversus (Bukry and Bramlette, 1969) Bukry, 1981

\section{ACKNOWLEDGMENTS}

We thank Drs. D. Bukry and B. U. Haq for reviewing this manuscript and for offering many helpful comments.

\section{REFERENCES}

Bukry, D., 1972. Coccolith stratigraphy-Leg 14, Deep Sea Drilling Project. In Hayes, D. E., Pimm, A. C., et al., Init. Repts. DSDP, 14: Washington (U.S. Govt. Printing Office), 487-494.

1973. Low-latitude coccolith biostratigraphic zonation. In Edgar, N. T., Saunders, J. B., et al., Init. Repts. DSDP, 15: Washington (U.S. Govt. Printing Office), 685-703.

1975. Coccolith and silicoflagellate stratigraphy, northwestern Pacific Ocean, Deep Sea Drilling Project Leg 32. In Larson, R. L., Moberly, R., et al., Init. Repts. DSDP, 32: Washington (U.S. Govt. Printing Office), 677-701.

Gartner, S., 1977. Calcareous nannofossil biostratigraphy and revised zonation of the Pleistocene. Mar. Micropaleont., 2:1-25.

Martini, E., 1971. Standard Tertiary and Quaternary calcareous nannofossil zonation. In Farinacci, A. (Ed.), Proc. II Plankt. Conf. Roma 1970 (Vol. 2): Rome (Edizione Tecnoscienza), 739-785.

Okada, H., and Bukry, D., 1980. Supplementary modification and introduction of code number to the low-latitude coccolith biostratigraphic zonation (Bukry, 1973, 1975). Mar. Micropaleont. $5: 321-325$. 